\title{
Valorizando o Exame Clínico
}

\author{
Coordenaçāo Editorial \\ Linamara Rizzo Battistella \\ Andréa Dompieri Furlan \\ Marcelo Morito Ikegami
}

Autores

\begin{abstract}
Alexandre Angelo Zereu - RS
Médico Fisiatra do Hospital-Infantil Presidente Vargas Porto Alegre

Andréa Dompieri Furlan - SP

Médica Residente da Divisão de Medicina de Reabilitação HCFMUSP

Armando Pereira Carneiro - MG

Diretor Científico SBMFER

Chefe do Departamento de Neurofisiologia Clínica do Hospital Arapiara

Membro do Conselho de Administração do Hospital Arapiara

Antônio Cardoso dos Santos - RS

Professor de Reabilitação Médica do Departamento de Cirurgia da Faculdade de Medicina da UFRS

Médico Fisiatra Chefe do Serviço de Fisiatria do Hospital de Clínicas de Porto Alegre

Membro da Academia Brasileira de Medicina de Reabilitação
\end{abstract}

Antônio Sérgio A. P. Terreri - SP Médico Fisiatra

Assistente da Divisão de Medicina Física do IOT - HCFMUSP

Carlos Alberto dos Santos - SP

Médico Ortopedista da Divisão de Medicina de Reabilitação do HCFMUSP - Médico Assistente Supervisor da Divisão de Medicina de Reabilitação do HCFMUSP

Doutorado pela FMUSP na Área de Ortopedia e Traumatologia

Claudete Lourenço - SP

Médica Fisiatra

Diretora do Serviço Médico da Divisão de Medicina de Reabilitação - HCFMUSP

Gilberto Fonseca - MG Presidente SBMFER

Membro do Conselho de Administração do Hospital Arapiara

Gilda de Matos Milman - RS

Professora do Departamento de Clínica Médica da Faculdade de Medicina da Universidade Federal de Pelotas - Professora

Responsável pela Disciplina Clínica Ambulatorial de Adultos Médica Fisiatra Responsável pelo Serviço de Fisiatria da

Faculdade de Medicina da Universidade Federal de Pelotas
Gilson Tanaka Shinzato - SP

Médico Fisiatra

Médico Assistente da Divisão de Medicina de Reabilitação do HCFMUSP - Coordenador do Setor de Avaliação Isocinética da DMR - HCFMUSP

Helena Seguchi Haziyoma - SP

Médica Fisiatra Responsável pelo Grupo de Síndromes Miofasciais da Divisão de Medicina Física do IOT - HCFMUSP - Mestranda pela FMUSP

Linamara Rizzo Battistella - SP Médica Fisiatra

Diretora da Divisão de Medicina de Reabilitação - HCFMUSP

Professora da Pós-graduação da FMUSP

Diretora Cientifica da APM - 93/95

$$
\begin{aligned}
& \text { Lin Tchia Yeng - SP } \\
& \text { Médica Fisiatra }
\end{aligned}
$$

Assistente da Divisão de Medicina Física do IOT-HCFMUSP Mestre pela FMUSP

Marcelo Morito Ikegami - SP

Médico Residente da Divisão de Medicina de Reabilitação HCFMUSP

\section{Margarida Harumi Miazaki - SP} Médica Fisiatra

Supervisora da Equipe Médica de

Hemiplegia da Divisão de Medicina de Reabilitação HCFMUSP

$$
\begin{aligned}
& \text { Marta Imamura - SP } \\
& \text { Médica Fisiatra }
\end{aligned}
$$

Assistente da Divisão de Medicina Física do IOT - HCFMUSP

Mestre da FMUSP

Raimundo E. de Araújo Leitão - RJ

Prof. Titular de Medicina Física e Reabilitação da Faculdade de Medicina da UFRJ

\section{Satiko Tomikowa Imamura - SP Médica Fisiatra}

Diretora da Divisão de Medicina Física do IOT- HCFMUSP Supervisora do Programa de Residência em Medicina Física e Reabilitação 


\section{Avaliação Fisiátrica do Amputado}

\section{Introduçāo}

Nosso roteiro de Avaliação Fisiátrica do Amputado será sucinto, visando orientar o médico na condução dos casos, de maneira segura e eficiente. Nos portadores de amputações de membros, o que mais importa é a pessoa e não o membro amputado, daí a necessidade de uma abordagem global do paciente, buscando o máximo de suas potencialidades não só no aspecto físico, mas também psicossocial, familiar e profissional. É indispensável a memorização das principais causas e complicações das amputações para a realização da avaliação.

Principais causas das amputações:

- vasculopatias periféricas;

- traumáticas;

- tumorais;

- infecciosas;

- congênitas;

- iatrogênicas.

Principais complicações nas amputações:

- deiscência de suturas;

- edemas;

- ulceração nos cotos;

- inflamação;

- infecção;

- retração cicatricial;

- dor (no coto ou fantasma);

- neuromas;

- espículas ósseas;

- hipotrofias e hipotonias;

- contraturas musculares;

- osteoporose (regional).

A causa mais freqüente é a vasculopatia periférica, acometendo principalmente a faixa etária após os 50 anos, sendo os MMII os mais comprometidos. As causas traumáticas atingem um grande número da população, quer seja por acidentes de trânsito, de trabalho ou qualquer outra etiologia. De uma maneira geral, os "acidentes de trabalho " culminam com amputações em MMSS, principalmente nas mãos. 
As sete primeiras complicações citadas são as mais precoces, ou seja, afetam o coto quase sempre até a segunda ou terceira semana após a amputação. As cinco seguintes aparecem mais tardiamente, embora a dor poss̀a apresentar-se em qualquer época e com características diferentes. Todos os esforços devem ser feitos visando a abolição da dor, e as complicações devem ser reparadas, corrigidas ou eliminadas para que seja possível a seqüência normal do programa de reabilitação do amputado.

Fenômeno comum nos portadores de amputação é o "fantásmico", citado pelo paciente conforme a percepção do mesmo. Se doloroso ou não, normal ou deformado, estará presente em cerca de $95 \%$ dos amputados. Até a terceira semana após a amputação (aproximadamente), a maioria dos amputados manifesta a percepção fantásmica de um membro normal e indolor, e alguns já referem um membro fantasma deformado a partir da primeira semana. Geralmente após a terceira semana da amputação, a "percepção" começa a sofrer deformação, isto é, a impressão de que o membro amputado existe, porém contorcido ou desproporcional, e para que seja rotulado como tal, não deve apresentar dor. A percepção de membro fantasma doloroso pode manifestar-se em membro fantasma normal ou deformado, sendo a dor caracterizada como leve a moderada, tolerável, respondendo satisfatoriamente à terapêutica física ou medicamentosa, podendo durar semanas a anos. A dor fantasma é sempre grave, intensa, resistente às inúmeras formas de terapias, chegando a impedir o programa de reabilitação. Pode aparecer precoce ou tardiamente à amputação e apresenta duração imprevisível, sendo satisfatório transformar esta dor fantasma em membro fantasma doloroso. A dor no coto tem localização específica no mesmo, sendo caracterizada por desprazer leve, moderado ou intenso, conseqüente a uma ou mais complicações.

Lembramos que o procedimento de amputação é muito mais um ato médico de restauração de um membro enfermo e da pessoa que o porta do que uma mutilação. Cabe a nós, profissionais da área de saúde no campo da reabilitação, valorizar a capacidade residual dessa pessoa restaurada para proporcionar sua recuperação total.
Idade

Sexo, peso corporal, nivel cultural $\theta$ profissão

Observação
Inspeção

Outras patologias associadas

Aspecto socioprofissional

Aspectos gerais

Rede circulatória

Sistema endócrino

\section{Identificação}

Nome completo, nacionalidade, naturalidade, data de nascimento (idade, sexo, estado civil, endereço, peso corporal, altura, profissão, grau de instrução, outros...).

A idade vai nos informar até sobre o potencial de capacidade laborativa residual, orientando-nos também para o planejamento do programa de reabilitação e protetização. Aspectos técnicos da protetização sofrerão modificações conforme o SEXO, PESO CORPORAL, NÍVEL CULTURAL e PROFISSẪ. Desde o primeiro contato com o paciente, é fundamental a atenção do médico para a observação ou inspeção, verificando sua postura e atitude (passiva ou ativa). Queixa e duração da enfermidade, história pregressa da moléstia atual, causas da amputação, complicações, patologias outras associadas, e aprofundar-se no, de vez que a reabilitação é um processo dinâmico que busca atingir o máximo de potencialidade do portador de limitação física.

\section{Exame Físico Geral}

Em nada será diferenciado do realizado em qualquer paciente, portador de qualquer patologia, onde investiga-se o funcionamento de todos os órgãos e aparelhos, aspectos gerais, estado nutricional etc. Considerando que a maior causa de amputação de membros deve-se às patologias vasculares periféricas, a investigação da rede circulatória merece cuidados especiais, bem como o sistema endócrino associado ao diabetes, favorecendo para um grande número de amputações. 
Membros não

amputados

Coto de amputação

Observação
Hipotonia
Hipotrofia
Coto

Pulsos

Contraturas

musculares

Articulações

Teste muscular

A.V.D.s

"Bateria padrão"

Anatomia, etiologia e função

Causa da

amputação

\section{Exame Físico Especial}

Quanto mais funcional e melhor estiverem os membros não amputados e o coto de amputação, maior será a possibilidade de um processo reabilitacional eficiente; o programa terapêutico nunca deve ser específico ao coto; no caso dos portadores de I.VP. os cuidados com o MI não amputado, submetendo-o também à reeducação muscular, são tão importantes quanto o tratamento do coto. A observação dos membros não amputados é indispensável, com ênfase nos amputados vasculares, onde podemos detectar hipotonia e hipotrofia do membro, alteração na distribuição dos pelos e na pele. A observação do coto quanto à forma (cilíndrico, cônico, piramidal, bulboso, bífido ou irregular), lado amputado (direito, esquerdo ou bilateral), nível de amputação (fazer a descrição), cicatriz cirúrgica (transversa mediana, anterior, posterior, radiada, aderente, com fístulas, outras) e coloração, deve ser completa. As medidas do coto quanto ao comprimento e diâmetros são de grande importância, quer seja para determinação do tipo de prótese a ser indicada ou para acompanhamento da evolução da normalização do diâmetro do coto. Semanalmente repete-se a medição do diâmetro do coto até que se tenha certeza que o mesmo esteja normal para o nível de amputação. Na palpação nunca esquecer os pulsos, principalmente nos amputados vasculares, sendo os MMII os mais comprometidos. Pela palpação tem-se a percepção da consistência do coto, se dura, média ou branda; se existem contraturas musculares, pontos dolorosos, quase sempre causados por espículas ósseas ou neuromas; se a cicatriz está aderente a planos profundos e se a temperatura do membro e do coto estão normais. É obrigatório o exame da articulação imediatamente superior ao nível de amputação, com maior atenção nos amputados de etiologia traumática. O mecanismo do trauma quase sempre é complexo, gerando lesões à distância. Qualquer alteração na A.D.M. articular será prejudicial para uma perfeita confecção da prótese. $O$ teste muscular com a determinação do grau de força muscular vai orientar o programa cinesioterápico, considerando-se o sexo e faixa etária. Faz parte também do exame físico especial a observação quanto às atividades de vida diária (A.V.D.s) no que diz respeito à movimentação e agilidade corporal, higiene, alimentação, vestuário e locomoção; abordando independência, transferências, ortostatismo e marcha.

\section{Exames Complementares}

Estarão indicados todos os exames necessários para observação do quadro clínico do paciente, para esclarecimento ou controle de qualquer das complicações, ou para acompanhamento da evolução. Não existe uma "bateria padrão" de exames. O médico em sua observação clínica julgará conforme o caso, a necessidade ou não de solicitação de exames complementares. A preocupação tem sido desde o início, a de traçar um roteiro flexível, sugerindo ou lembrando alguns tópicos específicos aos amputados, porém, sem "formatá-lo" rigidamente, face a inúmeras variáveis que poderão apresentar-se.

\section{Diagnóstico}

O diagnóstico da amputação propriamente dita é facílimo, pois a ausência do membro é visível não só aos olhos dos médicos, mas a qualquer pessoa. Sua importância está na anatomia, etiologia e na própria função, devendo ser registrado corretamente pelo médico. Para a determinação correta do diagnóstico é imprescindível o conhecimento das causas das amputações e dos níveis de 
Nível da amputação

Diagnóstico primário e secundário Complicação

Tratamento global

Complicações

Coto

Prognóstico de reabilitação

Prognóstico de protetização

Avaliação fisiátrica do amputado

Diagnóstico primário amputações. A amputação propriamente dita é conseqüência de uma enfermidade, merecendo o rótulo de diagnóstico primário ou principal, enquanto a amputação estaria com a denominação de diagnóstico secundário. O diagnósticu da complicação é o mais importante no que se refere ao procedimento da amputação e ao coto, e quanto mais precoce, mais rápido serão o controle e a cura, e melhor será o desempenho do paciente no programa de reabilitação.

\section{Tratamento}

O tratamento global do paciente determinará o êxito de toda a trajetória reabilitacional percorrida. Talvez tão importante quanto a terapêutica, seja a instituição da mesma em cada fase de evolução e de acordo com a necessidade. No aparecimento das complicações (neuromas, espículas, infecções, deiscências, edemas etc.), o tratamento específico deve ser preconizado tão logo seja diagnosticado. O objetivo final esperado com a instituição da terapêutica global é capacitar o paciente com o máximo de suas potencialidades para tornar-se independente para as A.V.D.s. Isto inclui o tratamento do coto, deixando-o indolor, com boa força muscular, sem edema, apto para receber o soquete protético. $O$ planejamento do tratamento fisiátrico no aspecto farmacológico, físico (pré, peri e pós-protético), psicossocial e profissional é fundamental para o bom desempenho do programa.

\section{Prognóstico}

Na perspectiva de prognosticar sobre reabilitação do amputado após a conclusão da avaliação fisiátrica, devemos diferenciar claramente a natureza do prognóstico visto por dois ângulos: prognóstico sob o ponto de vista de reabilitação $e$ sob o ponto de vista de protetização. Protetização não é sinônimo de reabilitação: sempre haverá potencial para reabilitação, por mínimo que seja, enquanto que em alguns casos não poderá ocorrer protetização. Reabilitação é um procedimento terapêutico global que transcende o corpo físico, e protetização é o emprego de recursos técnicos especializados visando a substituição parcial do "corpo físico". Desde que possível, no paciente amputado, a reabilitação será mais completa se for concluída com a protetização. Em Medicina, o prognóstico poderá ser sempre bom, regular, ou mau, e não será diferente para as deficiências físicas. Nas amputações de membros, atento à diferenciação sugerida, o fisiatra deve especificar seu suposto prognóstico.

\section{Conclusāo}

Ao encerrar esta "minuta" sintética de proposição para avaliação fisiátrica do amputado, esclarecemos que a proposta é muito mais de orientação do que o esgotamento do assunto. Com base nas informações aqui prestadas, o médico deverá ampliá-las na utilização prática, flexibilizando-a conforme o diagnóstico primário e as variáveis de cada caso. Seria necessário um compêndio para descrever-se todas as variantes de uma completa avaliação do assunto, porém, o objetivo do trabalho é extremamente modesto, servindo de "lembrete" a todos que se interessarem em avaliar amputados. 


\section{Protocolo de Atendimento nas Patologias Dolorosas do Ombro}

\section{Introduçāo}

O ombro é formado por um sistema articular complexo, possuindo grande amplitude articular. Com a realização da minuciosa semiologia podemos compreender um pouco do seu sistema de equilíbrio, sem deixar, no entanto, de se fazer um diagnóstico correto.
Neste protocolo serão abordados de forma objetiva e prática os principais passos na realização da anamnese e exame físico, no que diz respeito à propedêutica do ombro, que será importante, não só para a conclusão diagnóstica, como também para a orientação terapêutica.
Idade

Profissão

Queixa e duração

Tratamentos prévios e resultados

Dominância

Dor

\section{Identificaçāo}

$\mathrm{Na}$ infância ocorre casos de patologia obstétrica ou congênita, como as paralisias obstétricas ou deformidade de Sprengel, respectivamente. Nos adolescentes e adultos temos, principalmente, macrotraumas e microtraumas de repetição, havendo, respectivamente casos de fratura/luxação e tendinites. Nos idosos podemos encontrar pacientes com ruptura do manguito rotador, artroses, ou seja, patologias relacionadas com alterações degenerativas.

Algumas patologias estão relacionadas com uma sobrecarga sobre a articulação do ombro, e por isso deve ser investigado o tipo e a carga de trabalho que o indivíduo exerce. Pode ser que o trabalho não seja tão intenso (como carregar grandes pesos), mas pode ocorrer de os movimentos que o ombro realiza são variados e repetitivos, e podem estar causando microtraumatismos, como "LER" (lesão por esforço de repetição). Um exemplo disso é a profissão de caixa de supermercado que sobrecarrega o ombro esquerdo nos movimentos do seu trabalho.

\section{História}

Perguntar o que levou o paciente a procurar o serviço médico, e a quanto tempo esta queixa o vem inomodando.

Investigar quais foram os tratamentos prévios já realizados, incluindo: medicação, exercícios, fisioterapia, aplicação de calor ou frio, cirurgias, acupuntura etc.

Ocorre maior incidência de acometimentos no lado dominante, que normalmente apresenta maior sobrecarga.

Caracteriza-se por ser a queixa mais importante do paciente na semiologia. Embora apresente um caráter subjetivo, devemos caracterizar todos seus aspectos, como seu início (insidioso ou súbito), tipo, localização, irradiação, fatores de piora e/ou melhora, freqüência, duração e intensidade.

Perguntar também por fatores desencadeantes: os traumas podem ser macro ou microtraumas, sendo este último mais freqüente e conhecidos como LER (lesão por esforço de repetição). No meio esportivo estas lesões são conhecidas como "overuse". Devemos investigar os mecanismos de trauma e suas implicações biomecânicas, pois isto facilitará não só no diagnóstico, como na reabilitação. Lembrar que fraturas, luxações e lesões nervosas podem estar associadas com 
Amplitude do Movimento

AVD e Nivel de Atividade

Sono

\section{Geral}

Inspeção Estática macrotraumas; tendinites e dores miofasciais estão mais relacionadas com microtraumas. As rupturas podem estar associadas a ambas.

A instabilidade representa os casos de subluxação ou luxação, podendo estar relacionada à frouxidão da cápsula articular ou seção anatômica do complexo articular devido a trauma. Devemos avaliar quanto ao seu fator desencadenante e mecanismo, desde a época do primeiro episódio, como eventuais recidivas, e a implicação nas atividades de vida diária.

Em relação aos movimentos, investigaremos a amplitude articular, perguntando se existe sua diminuição ou aumento. A diminuição pode ser devido a dor, onde as tendinites e as dores miofasciais são causas freqüentes, ou devido a rigidez articular, seqüela de trauma não reabilitado ou por capsulite adesiva; diminuição por fraqueza muscular, ocasionada por ruptura do manguito rotador, como também lesão do nervo axilar (m.deltóide) ou nervo supraescapular (m. supraespinhal $/ \mathrm{m}$. infraespinhal); poderemos ter amplitude diminuída também pelo medo do ombro "sair do lugar", como ocorre nas luxações. O aumento da amplitude é encontrado na frouxidão articular ou nos quadros de hipermobilidade.

Devemos saber como o paciente se apresenta frente às atividades de vida diária (AVD), pois nos dará noção das dificuldades em seus graus diversos, seja no setor profissional, no lar, lazer ou esportes.

A dor pode prejudicar o sono pelas posições que o paciente assume. Devese ter isto em consideração para que no momento do tratamento deste paciente seja tomada alguma precaução sobre este problema.

\section{Interrogatório sobre demais Aparelhos}

Algumas causas possivelmente relacionadas com a capsulite adesiva são: discopatia cervical, infarto do miocárdio, patologia intracraniana, infecção pulmonar e hipertireoidismo ${ }^{(4)}$.

Em geral, as patologias reumatológicas podem estar associadas com outros sintomas além daqueles encontrados no ombro: polimialgias, febre, astenia, alterações na pele etc.

\section{Antecedentes Pessoais e História Familiar}

Investigar a existência de possíveis patologias relacionadas com problemas nos ombros:

Doenças reumatológicas: pode provocar monoartrites, poliartrites, artroses;

Diabetes: pode estar relacionado com capsulite adesiva;

Anemia falciforme: hemartroses, hemorragias intra ou intermusculares, hemorragias do subcutâneo;

Epilepsia: traumas, uso de anticonvulsivantes podem ser relacionados com capsulite adesiva;

Acidente Vascular Cerebral: pode provocar subluxação ou luxação do ombro;

Artrite Infecciosa: pode levar a dor e edema da articulação;

\section{Exame Físico}

Importante para avaliar o estado geral da saúde do paciente.

Tem como objetivo avaliar alterações, sejam de origem anatômica ou posturais, devendo ser comparativa, com o paciente em posição ortostática. Portanto, avaliaremos as más posturas devido a cifose, escoliose, a elevação da 
Inspeção Dinâmica

Palpação

Provas funcionais

Testes Clínicos escápula (deformidade de Sprengel), retração da escápula (lesão do nervo torácico longo); hipotrofias musculares por desuso e/ou lesões nervosas, por exemplo do nervo axilar (músculo deltóide), do nervo supraescapular (m. supraespinhal/m. infraespinhal), lesões do plexo braquial ou também devido a rupturas tendíneas (m.supraespinhal, m.infraespinhal, cabeça longa do m.bíceps braquial), assimetria articular (luxações acromioclavicular, esternoclavicular ou mesmo subluxação/ luxação glenoumeral), alterações da pele (equimose por trauma).

\section{Amplitude Articular}

Será avaliada através das movimentações ativa (inicialmente) e passiva, sempre comparativamente. Normalmente os arcos de movimento do ombro são: flexão/extensão $\left(180^{\circ} / 60^{\circ}\right)$; abdução/adução $\left(180^{\circ} / 45^{\circ}\right)$; rotação externa/interna $\left(100^{\circ} / 80^{\circ}\right)$.

Os movimentos do ombro são complexos e para que eles sejam realizados normalmente é preciso que algumas estruturas e sistemas estejam íntegros, como por exemplo:

1. integridade articular;

2. integridade óssea;

3. integridade das partes moles: músculos, força muscular, tendões, ligamentos etc;

4. propriocepção;

5. ausência de dor;

6. nível de consciência, desejo de realizar o movimento.

A fim de que a visualização dos resultados deste exame sejam mais fáceis, usa-se a representação em diagramas de cada movimento. Por exemplo: paciente tem flexão=150; extensão normal; abdução $=90$; adução $=20$; rotação interna e externa normais. A representação deste paciente deve ser:
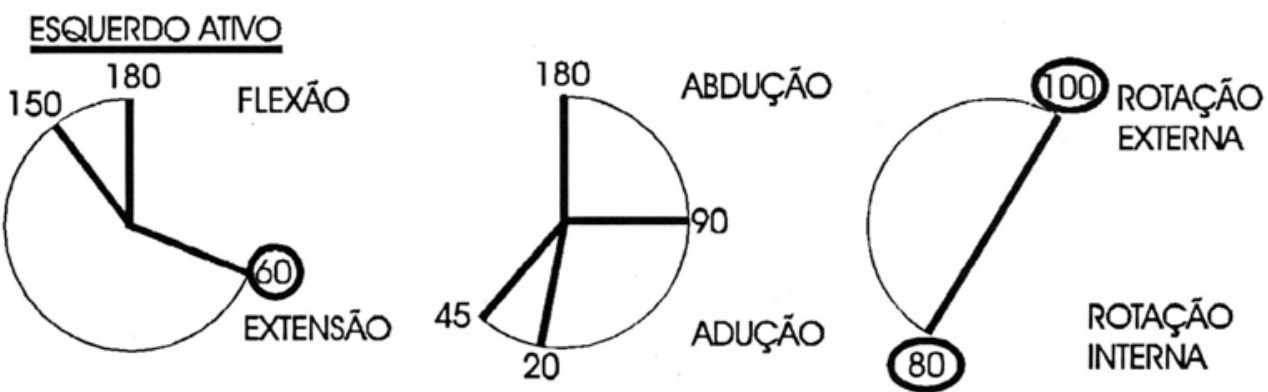

Deve-se palpar estruturas que tem importânica clínica devido a dor.

\section{Testes Clínicos Funcionais}

Averiguamos também as chamadas provas funcionais, que auxiliarão nas possíveis restrições do paciente para as AVDs. Assim, avaliamos ativamente as posições combinadas:

- abdução-rotação externa: mão-boca; mão-teste; mão-nuca.

- abdução-rotação interna: mão-coxa homolateral; mão-nádega; mão-região sacral; mão-região lombar; mão-região torácica baixa e alta.

São exames clínicos especiais realizados para avaliação do quadro doloroso, grau de força muscular e de estabilidade articular, que auxiliarão no diagnóstico clínico. 
Sinal do Impacto (de Neer)

Teste de Neer

Arco doloroso (painful arc)

Teste da Abdução

Teste de Jobe

Teste para RI e RE
O examinador realiza a flexão passiva do ombro com uma mão, fixando a escápula do paciente com a outra mão, provocando dor nos casos de Síndrome do Impacto, devido à compressão das estruturas subacromiais situadas entre o tubérculo maior do úmero e acrômio (fig 1).

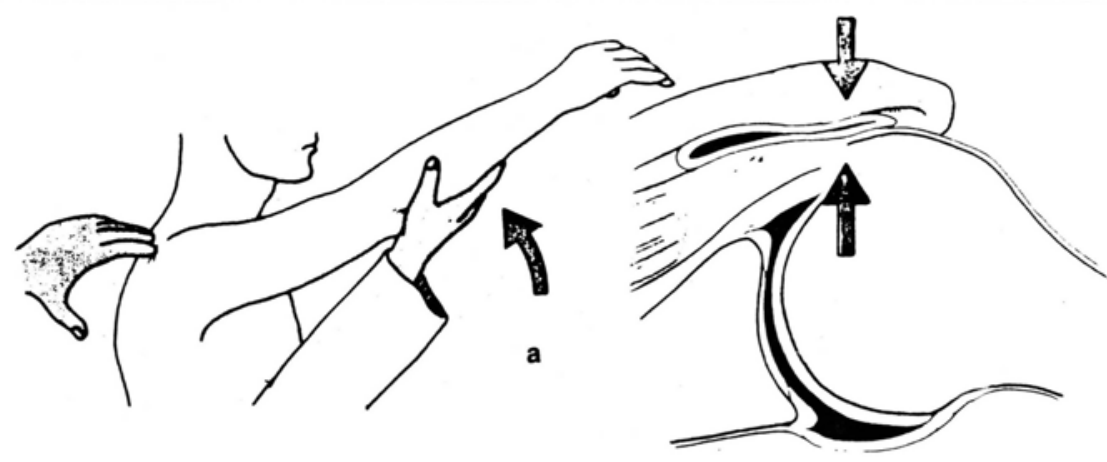

Fig.1. Sinal do Impacto (Neer).

Através da infiltração de 5 a $10 \mathrm{ml}$ de xilocaína no espaço subacromial, que uma vez positivo, aliviará a dor provocada pelo sinal de Neer (do impacto).

Dor situada entre os 60 e 120 de abdução ativa onde situa-se a zona de impacto; se a dor é provocada acima de 120 de abdução temos preferencialmente acometimento da articulação acromioclavicular.

Avaliação da força e/ou dor pela abdução, a partir de 0 , contra resistência do examinador (fig 2a).

Realizado para avaliação da dor e/ou fraqueza do músculo supraespinhal, através da abdução de 90 do ombro no plano da escápula contra resistência do examinador, estando o ombro em rotação interna ( polegar voltado para baixo) (fig 2b).
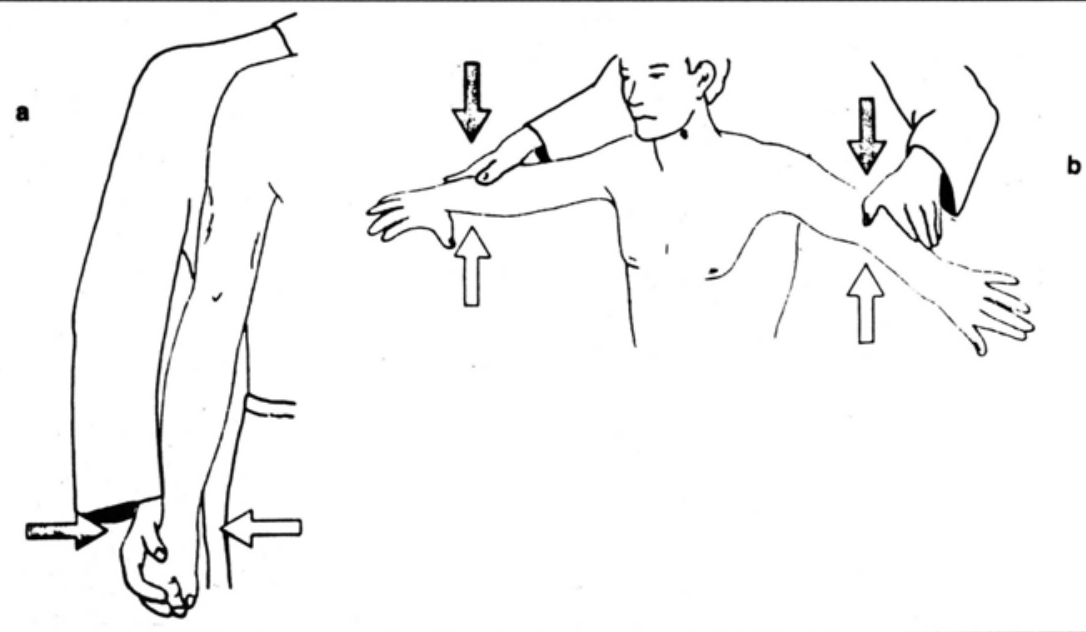

Fig. 2a. Teste da Abdução - 2b. Jobe

O teste para rotação interna e rotação externa é realizado isometricamente, tanto na posição neutra como abdução de 90 (fig 2c e d). 
Teste de Speed

Teste da Apreensão

Teste da Gaveta

Anterior e Posterior

Teste do Sulco
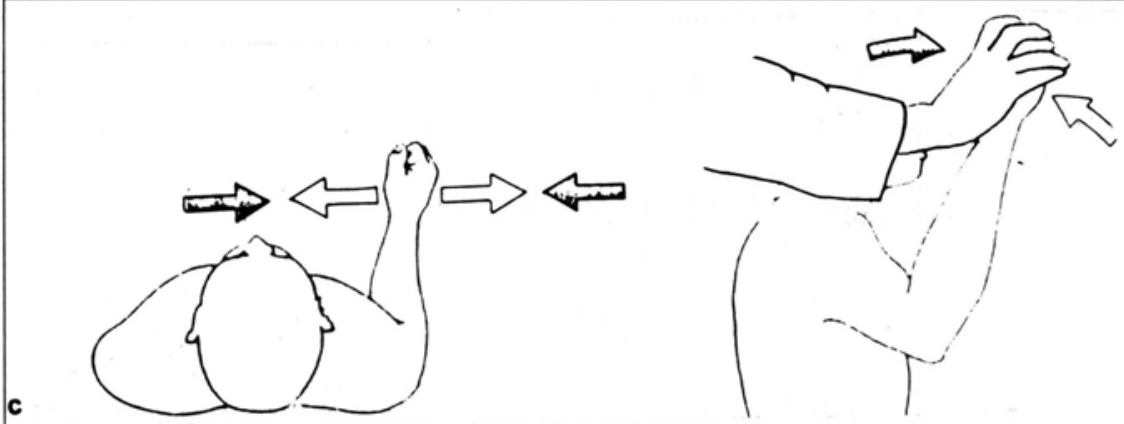

d

Fig.2c-d.Rotação externa/interna.

Realizado através da flexão do ombro contra resistência, estando o antebraço estendido e supinado. $O$ teste será positivo se provocar dor na cabeça longa do músculo bíceps braquial.

Para avaliar a estabilidade anterior e posterior, estando o paciente sentado ou deitado; para a apreensão anterior realizamos abdução (45 a 90$)$ combinado com rotação externa e ao mesmo tempo com a outra mão do examinador é exercida força anterior sobre a cabeça umeral. O paciente apresentará medo de subluxar ou luxar seu ombro. Para a apreensão posterior fazemos uma abdução, mas com rotação interna e força posterior. (fig 3a).

Serve para avaliar principalmente graus de frouxidão articular glenoumeral, estando o paciente sentado ou deitado. Ombro na posição neutra, uma mão fixa a escápula e a outra realiza movimentos de translação anterior e posterior sobre a cabeça umeral (fig $3 b$ e c).

Para avaliação da subluxação inferior da cabeça umeral na instabilidade multidirecional; fazemos uma tração inferior no braço do paciente com uma mão, fixando a escápula do paciente com a outra mão (fig $3 \mathrm{~d}$ ).

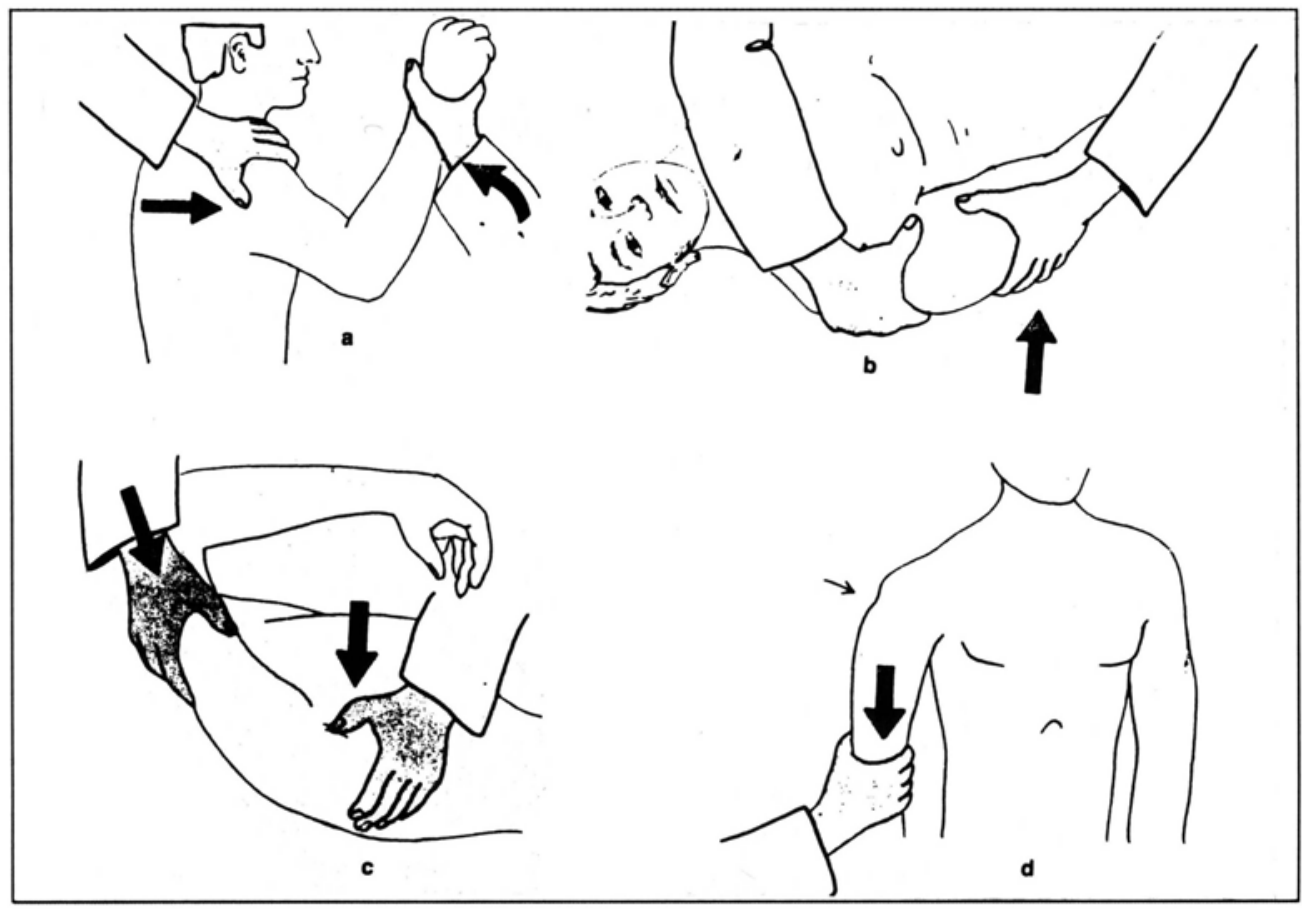

Fig. 3a Teste da Apreensão - 3b-c Teste da Gaveta - 3d Teste do Sulco 
Paciente deitado, executa-se o teste da apreensão, averiguando se há subluxação anterior e em seguida aplica-se com a mão do examinador força em sentido anteroposterior. Se houver persistência da dor, fala-se a favor do impacto; caso contrário, ou seja, na sua remissão, teremos instabilidade.

\section{Exames Complementares}

Anotar os resultados de exames tais como: raio X, ultra-sonografia do ombro, tomografia computadorizada etc.

\section{Diagnóstico}

Anotar os diagnósticos que foram feitos nesta consulta.

\section{Tratamento Proposto}

Anotar os tratamentos e as condutas que foram tomadas nesta consulta.

\section{Referências Bibliográficas}

1. FERREIRA Fo, A.A.; ZOPPI, A.; BOLLIGER, N.O.R.; FERREIRA, N.O.A.A. - Semiologia do ombro, Rev. Bras. Ortop. 23(4):93-98, 1988.

2. JAGER, M.; WIRTH, J. - Praxis der Orthopadie, Georg Thieme Verlag, Stuttgart, 1992. 


\section{Protocolo de Atendimento nas Patologias Dolorosas do Ombro}

\section{IDENTIFICAÇÃO}

Nome:

Idade:........... Sexo:. Estado civil:

Profissão atual/anterior:

Endereço:

Cidade:.

Data da consulta:

Telefone:

Médico: Raça: ( )branca ( )negra ( )amarela ( )vermelha

\section{ANAMNESE:}

Queixa e duração:.

Tratamentos e resultados:

Dominância: ( ) direita ( ) esquerda ( ) ambidestro

Características da dor:

- início:

( ) súbito

( ) insidioso

( ) após trauma

( ) microtraumas, "LER"

- tipo da dor: ( ) peso

( ) pontada

( ) choque

- freqüência: ( ) diária

( ) por semana ( ) por mês

- duração de cada episódio:

..... horas

..... dias

( ) agulhada

( ) por ano

- melhora:

- piora:.

- irradiação para:.

- intensidade da dor (VAS):

- esporte:

( ) nunca

....... quando está mais forte

..... semanas ..... meses

- fraturas:

( ) não

( ) esporádico

( ) profissional.

- luxações:

( ) não

( ) $\operatorname{sim}$

- instabilidade:

( ) não

( ) $\operatorname{sim}$

- lesões nervosas:

( ) não

( ) $\operatorname{sim}$

- tendinites:

( ) não

( ) $\operatorname{sim}$

( ) $\operatorname{sim}$

Amplitude Articular: ( ) normal ( ) diminuída ( ) aumentada

Atividades de Vida Diária:

- comer

- pentear o cabelo:

- escovar os dentes:

- vestir-se:

- banho:
( ) normal; ( ) independente com dificuldade;

( ) totalmente dependente;

( ) normal; ( ) independente com dificuldade;

( ) totalmente dependente;

( ) normal; ( ) independente com dificuldade;

( ) totalmente dependente;

( ) normal; ( ) independente com dificuldade;

( ) totalmente dependente;

( ) normal; ( ) independente com dificuldade;

( ) totalmente dependente;
( ) necessita ajuda;

( ) necessita ajuda;

( ) necessita ajuda;

( ) necessita ajuda;

( ) necessita ajuda; 

Sono:
( ) normal
( ) prejudicado pela dor
( ) outros distúrbios

Nível de Atividade:
- trabalho:
( ) normal
( ) pouco afetado
( ) muito afetado
- esporte:
( ) normal
( ) pouco afetado
( ) muito afetado
- lazer:
( ) normal
( ) pouco afetado
( ) muito afetado

\section{INTERROGATÓRIO SOBRE DEMAIS APARELHOS:}

- Neurológico:

- Otorrinolaringológico:

- Endócrino:

- Digestivo e nutricional:

- Cardiovascular:

- Pulmonar:

- Urogenital:

- Pele e fâneros

\section{ANTECEDENTES PESSOAIS:}

- doença reumatológica

- doença endocrinológica

- doença hematológica

- doença neurológica

- doença infecciosa

- doença traumática

- doença tumoral

- cirurgias prévias
( ) Artrite Reumatóide

( ) Diabetes

( ) Anemia Falciforme

( ) Epilepsia

( ) Artrite infecciosa

( ) não

( ) não

( ) não

( ) $\operatorname{sim}$

( ) $\operatorname{sim}$

( ) $\operatorname{sim}$
( ) Gota

( ) outras

( ) outras

( ) AVC

Qual?

Qual?

Qual?.

\section{ANTECEDENTES FAMILIARES:}

- doença reumatológica

- doença endocrinológica

- donça hematológica

- doença neurológica

- doença infecciosa

- doença tumoral
( ) Artrite Reumatóide ( ) outras

( ) Diabetes ( ) outras

( ) Anemia Falciforme ( ) outras

$\begin{array}{lll}\text { ( ) Epilepsia ( ) AVC } & \text { ( ) outras }\end{array}$

( ) Artrite infecciosa

Qual?.

\section{EXAME FÍSICO:}

\section{Geral:}
- Estado Geral:
( ) bom
( ) regular
( ) mau

- FC:. bat/min

FR:........... / $\mathrm{min}$

PA:...................... $\mathrm{mmHg}$

$\mathrm{T}: \ldots \ldots . . . . .{ }^{\circ} \mathrm{C}$

\section{Inspeção Estática:}

- postura:

- escápula:

- trofismo muscular:

- articulação:

- pele:
( ) normal

( ) normal

( ) normal

( ) normal

( ) normal
( ) cifótica

( ) elevada

( ) escoliótica

( ) hipotrofia

( ) luxada

( ) alterada
( ) outras

( ) outras

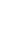




\section{Inspeção Dinâmica:}

- Amplitude Articular:

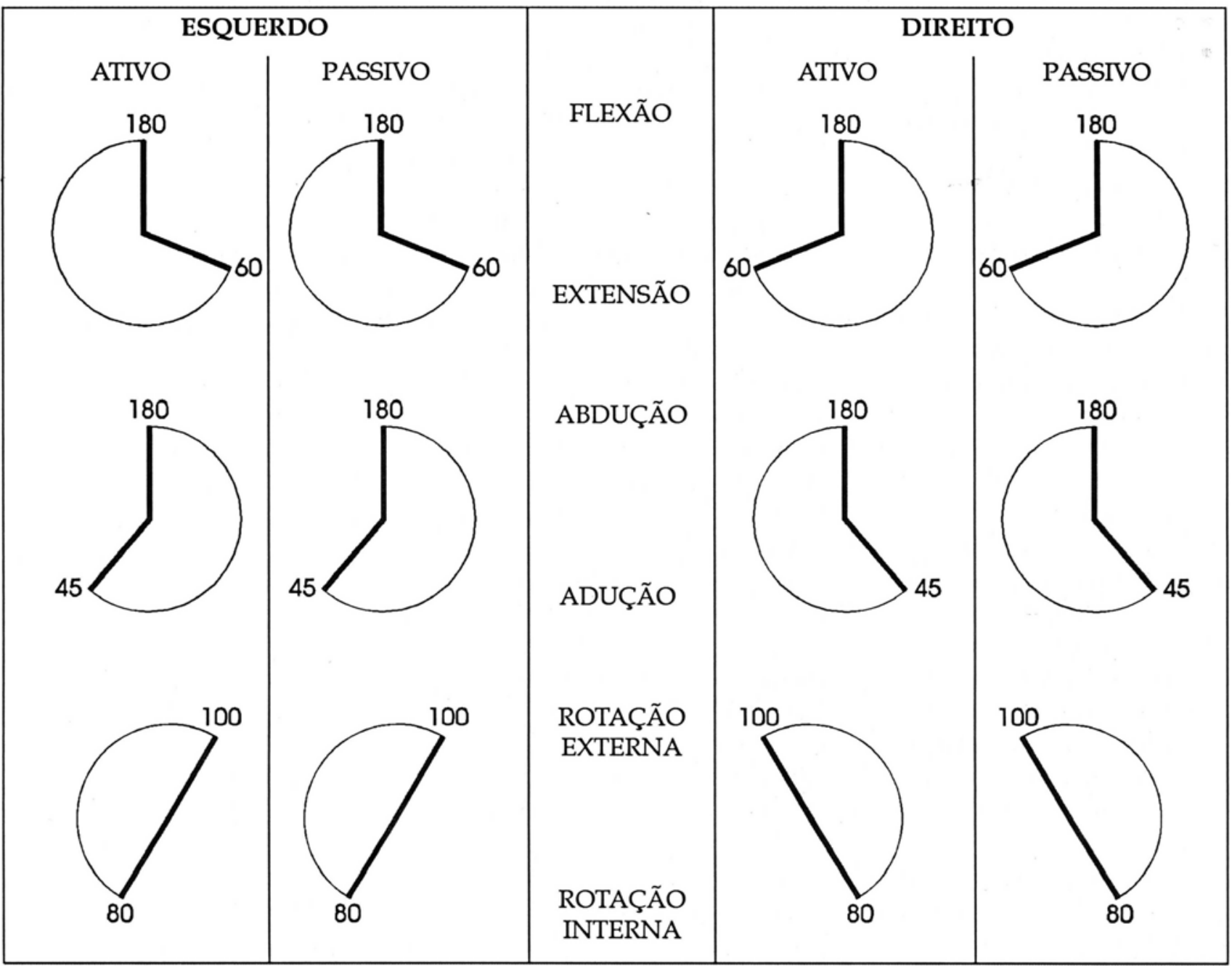

- Provas Funcionais:

Abdução e rotação externa:

\begin{tabular}{l|l|l|c}
\hline & sem problemas & dor e/ou dificuldade & não realiza \\
\hline mão-boca & & & \\
\hline mão-testa & & & \\
\hline mão-nuca & & & \\
\hline
\end{tabular}

Abdução e rotação interna:

\begin{tabular}{l|l|l|c}
\hline & sem problemas & dor e/ou dificuldade & não realiza \\
\hline mão-coxa homolateral & & & \\
\hline mão-nádega & & & \\
\hline mão-região sacral & & & \\
\hline mão-nível T 12 & & & \\
\hline mão-região interescapular & & & \\
\hline
\end{tabular}




\section{Palpação:}

- articulação acromioclavicular

- articulação esternoclavicular

- clavícula

- tubérculo maior

- tubérculo menor

- inserção do manguito rotador

- bursa subdeltoidea

- sulco intertubercular

- cabeça longa do m. bíceps

- pontos miofasciais:
( ) normal
( ) com dor
( ) crepitação
( ) normal
( ) com dor
( ) crepitação
( ) normal
( ) com dor
( ) crepitação
( ) normal
( ) com dor
( ) normal
( ) com dor
( ) normal
( ) com dor
( ) normal
( ) com dor
( ) normal
( ) com dor
( ) normal
( ) com dor
( ) fossa supra-espinhal
( ) fossa infra-espinhal
( ) região posterior da articulação glenoumeral
( ) região adutora e elevadora da escápula
( ) m. deltóide

Testes e Sinais Clínicos:

- Sinal do Impacto (Neer)

( ) sem dor ( ) com dor

- Teste de Neer

( ) não testado ( ) alívio da dor

( ) sem alívio da dor

- Arco doloroso

( ) sem dor

( ) dor entre 60 e $120^{\circ}$

( ) dor acima de $120^{\circ}$

- Teste da Abdução

( ) normal

( ) limitado por

- Teste de Jobe

( ) normal

( ) força diminuída

( ) normal

( ) limitado

- Teste para rotação interna

( ) normal

( ) limitado

- Teste de Speed

( ) negativo

( ) positivo

- Teste da Apreensão Anterior ( ) negativo

( ) positivo

- Teste da Apreensão Posterior ( ) negativo

( ) positivo

- Teste da Gaveta Anterior

- Teste da Gaveta Posterior

( ) negativo

( ) positivo

- Teste do Sulco

( ) negativo

( ) positivo

- Teste da Relocação

( ) negativo

( ) positivo

( ) normal

( ) instabilidade

EXAMES COMPLEMENTARES:

Exame:.

Data:. ..............

Resultado:

Exame:.

Data:

$. / \ldots \ldots \ldots . . .1$

Resultado:

Exame:

Data:.

Resultado:

\section{DIAGNÓSTICO:}

\section{TRATAMENTO PROPOSTO:}

1.

2.

3. 


\section{Protocolo de Atendimento nas Lesões por Esforços de Repetição}

\section{Introdução}

Este protocolo sobre Lesões por Esforços de Repetição (LER) foi realizado com o intuito de auxiliar nas avaliações dos pacientes portadores desta patologia. A tentativa é de tornar mais fácil e abrangente o questionário de avaliação clínica. $\mathrm{O}$ termo LER é amplamente utilizado e conhecido, mas existem outros termos comumente utilizados para a mesma patologia: Lesões por Traumas Cumulativos, Desordens Cervicobraquiais Ocupacionais, Síndrome de "Overuse", Distúrbios Músculo-esqueléticos Regionais, Distúrbios relacionados ao trabalho etc.

As Lesões por Traumas Cumulativos (LTC) são definidas como desordens dos tecidos moles causadas por esforços e movimentos repetidos. Apesar de poder ocorrer em quase todos os tecidos do corpo, os nervos, tendões, bainhas tendíneas e músculos da extremidade superior são os mais acometidos (1).

Estas lesões são causadas pela utilização biomecanicamente incorreta dos músculos, tendões, fáscias ou nervos, que resultam em dor, fadiga, queda do rendimento no trabalho e incapacidade temporária, podendo evoluir para uma síndrome dolorosa crônica, nesta fase agravada por todos os fatores psíquicos (no trabalho ou fora dele) capazes de reduzir o limiar de sensibilidade dolorosa do indivíduo ${ }^{(3)}$.

A repetitividade de um movimento é apenas um (e não necessariamente o mais importante) de um conjunto de 4 fatores biomecânicos e outros tantos fatores psicofísicos e sociológicos da realidade de trabalho que resultam na síndrome dolorosa.

Os quatro fatores contributivos mais importantes envolvidos na origem das Lesões por esforços de repetição são:

1. Força: quanto mais força exigir do trabalhador, tanto mais propenso estará o mesmo a desenvolver as LER.
2. Repetitividade: quanto maior o número de movimentos desenvolvidos pelo trabalhador em sua atividade, quanto mais freqüente forem os movimentos de um determinado grupo muscular, quanto mais freqüente for um movimento estereotipado, tanto mais freqüente o trabalhador desenvolverá as LER.

3. Posturas viciosas

4. Compressão mecânica: principalmente na base das mãos, local onde passa o nervo mediano.

Outros fatores contributivos para desenvolver LER são: vibração, frio, sexo feminino, postura estática durante o trabalho, tensão no trabalho, desprazer, traumatismos anteriores, atividades anteriores e perfil psicológico.

As LER englobam uma variedade de diagnósticos possíveis, o termo LER não é diagnóstico por si. O importante é que se diferencie a patologia exata que cada doente apresenta. Por ex:

1. Tendinite do músculo bíceps do braço

2. Lesões no manguito rotador

3. Síndrome do desfiladeiro torácico

4. Epicondilite medial ou lateral

5. Síndrome do interósseo anterior, com compressão do nervo mediano pelo músculo pronador redondo

6. Síndrome do interósseo posterior, com compressão do nervo radial pelo músculo supinador

7. Bursites

8. Síndrome do Túnel do Carpo

9. Dedo em gatilho

10. Cisto sinovial

11. Doença de DeQuervain

12. Síndrome dolorosa miofascial etc 
Profissão

Funções ocupadas

Trabalho

Tempo de aparecimento dos sintomas

Tempo de trabalho sem se afastar

Atividades realizadas no trabalho

Troca de função

Aspectos especiais

Dor

\section{Histórico ocupacional}

Devemos saber qual a atividade que o doente se preparou para exercer. Se fez curso profissionalizante, técnico ou de nível superior.

Perguntar sobre a função ou cargo ocupado, prestando atenção se a função ocupada pelo doente no momento em que iniciou os sintomas correspondiam à sua profissão. O preenchimento deve iniciar com a profissão atual e prosseguir retrogradamente. Anotar também se houve alteração de função dentro de uma mesma empresa (sem motivo relacionado com a dor).

Deve-se ressaltar alguns aspectos especiais do trabalho em relação à época do aparecimento da dor.

Este é um dado muito importante, assim podemos identificar áreas críticas dentro da empresa. Por ex: se os sintomas apareceram 2 meses após o início da atividade isto indica que aquela é uma área crítica. Se os sintomas apareceram 2 anos após, isto indica que aquela é uma área menos crítica.

Isto é de grande relevância, pois sabe-se que se o trabalhador que for afastado da função precocemente tem prognóstico melhor.

Devem ser listadas as atividades que são realizadas durante a jornada de trabalho. Por ex: flexão repetitiva dos dedos (digitação); flexão freqüente do punho (descascar e puxar fios); extensão freqüente do carpo (caixa de supermercado); flexão do cotovelo e empurrar objeto para trás (caixa de supermercado empurrando mercadoria na esteira)

Alguns movimentos predispõem a lesões bastante específicas. Por ex:

1. exercer esforço contra cabo de alicate ou tesoura predispõe o aparecimento de nódulos nos tendões dos dedos, ocasionando o dedo em gatilho (tendinite estenosante)

2. usar ferramenta que posiciona a mão em desvio ulnar (alicate de ponta reta, furadeira e parafusadeira) predispõe o aparecimento da tendinite de DeQuervain

3. esforço excessivo de extensão brusca do punho ocasiona a epicondilite lateral.

Troca de função em conseqüência da dor pode ser benéfica se as atividades forem diferentes. Esta tem sido uma prática muito comum nas empresas.

Algumas das situações que estão listadas são bem conhecidas como precipitadores das Lesões por Esforços de Repetição(3): temperatura ambiental fria; excesso da carga de trabalho; estresse gerado e se existe uma outra jornada de trabalho em casa, a "dupla jornada", comum em mulheres que trabalham fora e dentro de casa.

\section{Anamnese}

A dor é a queixa mais freqüente do doente com LER. É uma dor que angustia o trabalhador, compromete o seu humor, e eleva sua freqüência cardíaca basal em manobras que a desencadeiam. No início é sentida como peso, ou incômodo mal definido. Nas fases seguintes ela surge como queimação, aos mínimos movimentos, compromete as atividades de vida diária (AVD). A dor tende a se tornar constante e o doente se apresentar sempre com um dolorimento crônico 
Edema

Choque

Câimbras

Alteração da

Sensibilidade

Tremores

Atrofias

Fraqueza

Cansaço

Sono

Fadiga

Humor podendo ter episódios de agudização. Nas fases mais avançadas o doente consegue apontar com certeza o local de maior dolorimento, mas também há uma dor espalhada por todo o membro acometido. É interessante que o doente quantifique esta dor, podendo usar a Escala Visual Analógica - VAS (2) que será útil no seguimento da dor.

Pede-se ao doente para pintar no desenho os locais em que ele sente a dor.

Queixa freqüente, ocorre precocemente, predominando nas áreas mais comprometidas, costuma ser recorrente e pode se cronificar, produzindo deformidade e microfibrose devido ao prejuízo no retorno linfático.

Pode fazer com que o paciente deixe objetos caírem da mão, ou então acordar durante a noite. Costuma indicar compressão no nervo Mediano, mas não é sinal de Síndrome do Túnel do Carpo, pois a tenossinovite costuma ocasionar períodos de compressão do nervo por si só.

São menos freqüentes que os choques, e possuem o mesmo significado fisiopatológico.

Os formigamentos e dormências são queixas freqüentes e indicam sinais de compressão nervosa.

É a sensação de incoordenação dos movimentos.

É percebida como um emagrecimento muscular local, pode estar relacionada com lesão nervosa ou com desuso.

A perda de força muscular origina o sintoma de fraqueza. Ela pode indicar compressão nervosa. É uma queixa muito freqüente.

O doente refere que, após exercer alguma atividade que ele estava acostumado, ele sente a região como se tivesse feito um esforço muito grande.

Pode estar prejudicado por posicionamento desconfortável na cama e pela existência dos choques e dormências noturnos.

Nas fases mais tardias da doença o paciente se queixa de mal estar geral e cansaço crônico, ou então tal sintoma pode ser um indício precoce de fibromialgia.

Um doente com dor aguda se apresenta agitado, ansioso e falando bastante. Já um doente com dor crônica fica deprimido, quieto e falando pouco

- Depressão: lentificação dos processos psíquicos, humor depressivo, redução da energia (desânimo, cansaço fácil), dificuldade de concentração, desinteresse, apatia, perda da capacidade de planejar o futuro e alteração do juízo da realidade.(')

- Ansiedade: é uma emoção normal do ser humano que ocorre quando se antecipa uma situação de perigo. Torna-se patológica quando é muito intensa ou desproporcional ao estímulo que originou. Por ex: na consulta médica, sem nenhum perigo aparente, o paciente se apresenta taquicárdico, taquipnéico, sudoreico, com tremores, agitação psicomotora, reage assustado a pequenos estímulos. (7)

- Irritabilidade: é um sintoma que pode estar presente em várias patologias: epilepsia, psicopatia, psicose maníaco-depressiva, esquizofrenia e nos 
AVD e AVP

Fraturas

Patologia reumática

Uso de

anticoncepcional

Atividade fisica

Hobbie

Tabagismo, Etilismo e drogas processos demenciais. Caracteriza-se por predisposição afetiva para sentimentos desagradáveis como raiva, desgosto, mal-estar, mau humor, grande propensão a reações de agressividade ${ }^{(8)}$.

- Estresse: A reação aguda ao estresse é um transtorno transitório que surge em indivíduos sem qualquer outro transtorno mental aparente, como resposta a uma situação excepcionalmente estressante, seja ela física ou psíquica. Sua duração vai de horas a dias, e costuma se apresentar inicialmente como um estado de estupefação e algum estreitamento do campo de consciência, diminuição da atenção, inabilidade para compreender estímulos e desorientação. São comuns os sintomas autonômicos de ansiedade ${ }^{(7)}$.

O comprometimento nas Atividades de Vida Diária (AVD) e nas Atividades de Vida Prática (AVP) refletem o grau de intensidade da dor. Dependendo dos movimentos que estão limitados, isto vai nos auxiliar para identificar os músculos envolvidos, como por ex:

1. lesão no manguito rotador: pentear os cabelos, mexer no bolso traseiro, coçar as costas;

2. músculo esternocleidomastóide: dificuldade para girar o pescoço;

3. comprometimento nervoso: queda de objetos (fraqueza);

4. tenossinovites: dor para girar maçaneta da porta e de girar uma chave na fechadura.

\section{Interrogatório sobre Demais Aparelhos}

Avaliar a existência de outras alterações paralelas que não estão relacionadas com os movimentos, e que podem estar causando ou perpetuando as queixas do doente.

\section{Antecedentes Pessoais}

As fraturas e luxações do punho, cotovelo e ombro podem ser fatores predisponentes para desenvolver LER.

Alguns casos de LER têm um passado de patologia reumática, e nestes casos o diagnóstico diferencial deve ser muito bem feito, em função de comprometer o prognóstico.

O uso de anticoncepcionais orais aumenta a incidência de Lesões por Esforços de Repetição.

Musculação, levantar peso, ginástica com halteres, tênis, voleibol e golfe são atividades que precipitam as LER. São também fatores precipitadores: uso de instrumentos musicais, como violão, baixo, piano e violino.

Se o doente não tem nenhum hobbie, deve-se investigar se é porque ele não tem tempo, se ele não se interessa (não está psiquicamente estimulado) ou se é pelas dificuldades financeiras impostas pela doença.

\section{Hábitos} doente.

São fatores adicionais importantes que prejudicam ainda mais a saúde do 
Postura

Nódulos e Gânglios

Inflamação e

hiperemia

Palidez local

Deformidades

Incapacidades

Amplitude dos

Movimentos (ADM)

\section{Exame Físico}

Inspeção (descrever no espaço as alterações observadas)

A postura de defesa é comum: o ombro se apresenta desnivelado, o braço estendido na vertical e o antebraço fletido a 90 graus e na posição neutra.

Procurar especialmente os cistos sinoviais na região dorsal e ventral do punho, caso o trabalhador reclame de dor na mão, procurar nódulos junto da superfície articular dos dedos.

Comparar os dois lados, aparece com maior freqüência na superfície ventral do antebraço, no cotovelo e no punho.

O achado de palidez, mãos frias e sudorese palmar excessiva é bastante freqüente, é atribuído a uma distrofia simpático-reflexa. Em geral é unilateral.

Observar se são típicas de alterações articulares (ex: nódulos de Heberdein, deformidade em botoneira do dedo), nervosa (ex: garra ulnar), tendínea (ex: dedo em martelo) etc.

Durante a consulta deve-se ficar atento para as incapacidades que o paciente apresenta objetivamente. Nos casos de lesões relacionadas ao trabalho não é incomum a simulação dos sintomas para obter vantagens econômicas ou sociais.

Deve-se avaliar toda a coluna e os membros superiores. Se o paciente apresentar alguma queixa nos membros inferiores, deve-se prosseguir ao exame dos mesmos.

As amplitudes articulares dos ombros, cotovelos, punhos e mãos são medidas com um goniômetro e os valores normais estão indicados para cada extremidade do movimento( ${ }^{(4)}$; devem ser anotadas da seguinte forma: anotar entre os valores o grau de amplitude que o paciente atinge, se for normal pode fazer um círculo ao redor do valor impresso.

Por ex: Ombro direito com limitação para extensão $\left(30^{\circ}\right)$ e flexão $\left(60^{\circ}\right)$. Restante normal. Ombro esquerdo com limitação de todos os movimentos.
DIREITO

OMBRO 60_30_60_180 Extensão<smiles>C=[GeH2]</smiles>
(180) Adução ESQUERDO $\begin{array}{lllr}60 & 0 & 0 & 0\end{array}$

0_ $\quad 0 \_$_ 180

(90) RotaçãoInt _ RotaçãoExt 70_____ __ 90
O diagrama da coluna deve ser preenchido segundo o padrão:

- para dor: + dor leve que não impede o movimento ++ dor moderada que não impede o movimento

+++ muita dor que não impede o movimento

++++ limitação importante do movimento por dor forte

- para limitação: 0 se estiver normal

-1 se houver limitação ao movimento de apenas $25 \%$

-2 se houver limitação ao movimento de $50 \%$

-3 se houver limitação ao movimento de $75 \%$

-4 se houver limitação ao movimento totalmente 
Pontos dolorosos miofasciais

Tinel

Teste de Adson

Teste de Neer

Teste de Jobe

Yergason

Filkenstein

Teste de Phalen

Teste de Phalen invertido

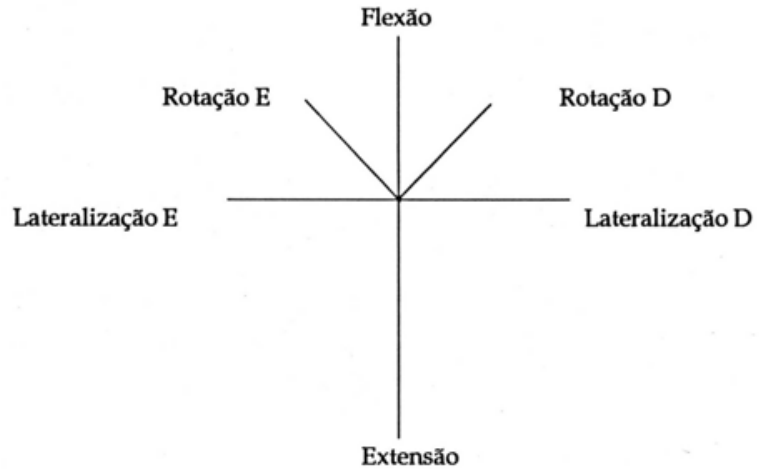

Palpação e testes especiais (6)

São pontos dolorosos dentro de um músculo ou fáscia muscular, sensíveis à digitopressão, com uma área específiça de dor irradiada.

É a digito-percussão sobre a área de um nervo. Será positivo quando produzir dor ou hiperestesia devido ao processo patológico estabelecido no nervo.

Avalia o grau de compressão do plexo braquial na Síndrome do Desfiladeiro Torácico. Palpação do pulso radial, com o paciente mantendo o membro superior abduzido em 90 graus e em rotação externa, e com a cabeça virada para o lado oposto ao lado testado.

Avalia o quadro de tendinite do manguito rotador, durante a compressão sub-acromial. A mão do examinador fixa a escápula na sua posição de repouso, enquanto a outra mão eleva rapidamente o membro superior do paciente, produzindo o impacto entre a grande tuberosidade da cabeça do úmero e a porção anterior e inferior do acrômio. $\mathrm{O}$ teste é positivo quando o paciente referir dor súbita.

Avalia a tendinite do manguito rotador, através da comparação da força de rotação externa entre os dois membros superiores, na posição de abdução em 90 graus.

Avalia a tendinite da cabeça longa do bíceps. Dor ao nível da goteira bicipital quando o paciente flete ativamente o cotovelo e supina o antebraço.

Avalia a tendinite de DeQuervain. Colocar o polegar aduzido e fletido dentro da palma da mão e mover rapidamente o punho em desvio ulnar. Haverá dor e desconforto pela passagem súbita dos tendões do extensor curto do polegar e abdutor longo do polegar, mais os tendões acessórios, por dentro do primeiro compartimento dorsal, que geralmente está septado e/ou reduzido devido à inflamação.

Avalia a compressão ao nervo Mediano, através da flexão do punho em 90 graus, causando pressão aumentada ao nível do túnel do carpo. Tem dor e hipoestesia em menos de um minuto, na respectiva área inervada.

Compressão do nervo Mediano no túnel do carpo 
Teste de Spurling

Teste de Valsalva

Marcha

Sensibilidade

Força

Coordenação

Motora

Reflexos
Avalia uma hérnia de disco vertebral cervical ou condições que produzam dor na raiz nervosa cervical ao nível da sua emergência. Compressão axial da cabeça com leves movimentos de lateralização. $O$ teste será positivo quando o paciente referir dor cervical com irradiação para o membro superior acometido.

Avalia hérnia de disco ou etiologia intratecal; solicita-se ao paciente que tussa ou sopre na mão, em caso positivo aparecerá dor local.

\section{Exame Neurológico}

Elementos importantes no diagnóstico diferencial que devem ser examinados:

Alguns padrões patológicos são importantes por poderem estar associados com alterações na função dos membros superiores: ataxia cerebelar, hemiparesia, di ou tetraparesia, Parkinsonismo ou marcha artrogênica.

O principal fator para ocorrer distúrbio da sensibilidade é a lesão no sistema nervoso. Esta lesão pode ser em vários níveis: Sistema nervoso central ou periférico (radicular, plexular ou nervos periféricos). Nos casos de LER pode-se encontrar: radiculopatias, plexopatias, mononeuropatias periféricas únicas ou múltiplas. O teste da sensibilidade epicrítica e protopática é importante na diferenciação destas lesões.

Nos casos de LER pode ocorrer diminuição da força por lesões nervosas, pela dor ou hipotrofia muscular por desuso. Deve-se verificar os principais movimentos de cada região: cervical, ombros, cotovelo, punho e mão. A graduação da força é feita da seguinte maneira ${ }^{(5)}$ :

- 0 Não há evidência de contratilidade

- 1 Evidência de pouca contratilidade, não havendo movimento articular

- 2 Movimentação completa eliminada a gravidade

- 3 Movimentação completa contra a gravidade

- 4 Movimentação completa contra a gravidade e com alguma resistência

- 5 Movimentação completa contra a gravidade e com resistência total

A coordenação motora é um encadeamento harmonioso, energeticamente eficaz da ação dos diversos músculos na realização de um movimento. Alguns testes podem ser feitos:

- Coordenação estática: prova dos braços estendidos, Romberg etc.

- Coordenação cinética: Index-nariz (com olhos abertos e com olhos fechados), diadococinesia, Souques etc.

- Bíceps: nível de integração C5C6, pode estar normal, diminuído, vivo ou exaltado

- Braquiorradial: nível de integração C5C6, pode estar normal, diminuído, vivo ou exaltado

- Tríceps: nível de integração $\mathrm{C6C7,} \mathrm{pode} \mathrm{estar} \mathrm{normal,} \mathrm{diminuído,} \mathrm{vivo}$ ou exaltado

- Estiloradial: nível de integração C7C8, pode estar normal, diminuído, vivo ou exaltado

- Hoffmann: indica lesão no sistema justapiramidal. Normalmente ele se encontra ausente 
Hemograma, VHS, Ácido úrico, Provas Reumáticas

Radiografias

Eletroneuro miografia

Ultra-sonografia Ressonância $e$ Tomografia

Lesões Existentes

Fases Clínicas (3)

\section{Exames Complementares}

As Lesões por Esforços de Repetição nos membros superiores são diagnosticadas clinicamente. Para tal é importante um exame clínico cuidadoso, conforme orientado anteriormente.

São importantes para diferenciar as Lesões por Esforços de Repetição, onde todos estes exames devem estar normais, das demais doenças que possuem tratamentos específicos, tais como: artrite reumatóide, gota, lupus etc.

Não há nenhum sinal específico para as Lesões por Esforços de Repetição, mas estes exames devem ser solicitados para afastar outras patologias: neoplásicas, fraturas etc.

Constitui-se numa das técnicas adequadas de exame complementar quando se suspeita estar havendo compressão de algum nervo (presença de formigamento, dormência e queda de objetos).

O ultra-som de partes moles (tendões) é uma técnica recentemente instituída e pode evidenciar compressões, estenoses ou edemas. Para este tipo de evidencialização, pode-se também utilizar a ressonância magnética e a tomografia computadorizada.

\section{Análise do Posto de Trabalho quanto ao Risco de LER}

A avaliação do posto de trabalho tem três finalidades:

1. identificar fatores biomecânicos contributivos para as LER

2. adotar medidas corretivas antes que os trabalhadores venham a ter problemas

3. permite remanejar trabalhadores em fase inicial da lesão

Há duas formas de se fazer esta análise:

1. completa: com recursos tecnológicos precisos

2. simplificada

Deve-se solicitar ao médico do trabalho da empresa que envie os resultados para serem anexados no prontuário do paciente.

Os fatores que podem ser analisados são: repetitividade, força, compressão mecânica, posturas, solicitações próprias da tarefa, psico-fisiológicas ou ergonômicas.

\section{Conclusōes Finais}

Listar os diagnósticos realizados, e o(s) lado(s) acometido(s)

Fase I

- Queixa: dor em peso nos braços ou nos ombros, piora com a jornada, melhora com repouso.

- Sinais: ausentes.

- Prognóstico: ótimo.

- Tratamento: facilitar o repouso programado; mudar a situação de trabalho; acompanhar as queixas quinzenalmente até a remissão dos sintomas.

\section{Fase II}

- Queixa: dor que incomoda, perturba o sono, períodos de alternância entre intensa e fraca. Piora com a jornada, mas ainda melhora com o repouso. Tem edema que piora com o movimento. 
- Sinais: temperatura das mãos diminuída, posição antálgica, palpação dolorosa dos músculos e tendões.

- Prognóstico: bom.

- Tratamento: afastar o trabalhador da atividade crítica; se houver dificuldade em remissão dos sintomas com o afastamento, incluir os antiinflamatórios não-hormonais.

Fase III

- Queixa: dor é sempre severa, constante, incapacitante para as mínimas atividades. Edema e fraqueza muscular são constantes.

- Sinais: Edema, calor local sobre os tendões, crepitações, padrão antálgico, mãos frias e sudoreicas, manobras muito dolorosas, aumento da freqüência cardíaca com as manobras que desencadeiam a dor.

- Prognóstico: reservado.

- Tratamento: afastamento do funcionário; efetuar tratamento clínico conservador; tratamento cirúrgico se houver compressão neural; medidas de suporte psicológico; acompanhar até a alta definitiva ( 3 a 6 meses).

Fase IV

- Queixas: Dor e invalidez.

- Sinais clínicos: não são tão exuberantes, mas existem.

- Estado psíquico muito alterado: neuroses são comuns devido à falta de informação sobre a sua doença; conceitos propagados de incurabilidade; tratamentos que não dão resultados; tentativas frustradas de voltar ao trabalho; prejuízo financeiro; falta de compreensão dos familiares; falta de interesse da empresa no seu caso; dores nas mínimas atividades, até no contato sexual.

- Prognóstico: ruim.

- Tratamento: esclarecer ao doente sobre a sua doença; reintegrá-lo de forma lenta na função; acompanhar os processos da reabilitação profissional.

\section{Tratamento}

Cada paciente deve ter um tratamento individualizado, que pode variar desde: medicação, cirurgias, medidas físicas, cinesioterapia, terapia ocupacional, órteses, psicologia, condicionamento físico, mudança de função, afastamento do serviço etc.

\section{Referências Bibliográficas}

1. ARMSTRONG, T.J. - Ergonomics and cumulative trauma disorders of the hand and wrist, IN: HUNTER, J.M.; SCHNEIDER, L.H. - Rehabilitation of the hand: Surgery and Therapy, pp. 11751191. 3rd Ed, C.V. Mosby Company, 1991.

2. CHAPMAN, R.S.; SYRJALA, K.L. - Measurement of pain; IN: BONICA, J.J. - The Management of Pain, 2nd Ed, Londres, Lea \& Febiger, vol 1, chapter 32, p.580-594, 1990.

3. COUTO, H.A. - Guia Prático Tenossinovites e outras Lesōes por esforços de repetição nos membros superiores de origem ocupacional, Ergo Editora B\&C, Belo Horizonte, 1991.

4. ERICKSON, R.P.; MCPHEE, M.C. - Clinical Evaluation, IN: DELISA, J.A.; GANS, B.M. - Rehabili tation Medicine, Principles and Practice, pp51-95, 2nd Ed, J.B. Lippincott Company, Phila delphia, 1993.

5. HOPPENFELD, S. - Propedêutica Ortopédica, Coluna e Extremidades, Atheneu, São Paulo, 1993.

6. LECH, O.; HOEFEL, M.G. - Protocolo de Investigação das Lesōes por Esforços Repetitivos.

7. LOUZĀ NETO, M.R.; MOTTA, T.; WANG, Y.P; ELKIS, H. - Psiquiatria Básica, Ed Artes Médicas, Porto Alegre, 1995.

8. SÁ JR, L.S.M - Psicopatologia e Propedêutica 1, Atheneu, São Paulo, 1984. 


\section{Protocolo de Atendimento nas Lesões por Esforços Repetitivos}

\section{IDENTIFICAÇÃO}

Nome:

Idade:

Sexo:.

Estado civil:

Raça: ( ) branca ( ) negra ( ) amarela ( ) vermelha

Endereço:

Cidade:

Telefone:

Procedência remota/atual:

Data da consulta: ......./....../.

Dominância: ( )Dir ( )Esq ( )Ambidextro

\section{HISTÓRICO OCUPACIONAL}

Profissão:

\begin{tabular}{l|l|l|l|l}
\cline { 3 - 4 } \multicolumn{1}{c|}{ Função Ocupada } & Nome da Empresa & $\begin{array}{c}\text { Data de } \\
\text { Admissão }\end{array}$ & $\begin{array}{c}\text { Data da } \\
\text { saída }\end{array}$ & $\begin{array}{c}\text { Sintomas } \\
(\mathrm{S})(\mathrm{N})\end{array}$ \\
\hline $1^{\mathbf{a}}$ & Atual: & & & \\
\hline $2^{\mathbf{a}}$ & Prévia: & & & \\
\hline $\mathbf{2}^{\mathbf{a}}$ & Prévia: & & & \\
\hline $1^{\mathbf{a}}$ & Prévia: & & & \\
\hline $2^{\mathbf{a}}$ & & & & \\
$\mathbf{1}^{\mathbf{a}}$ & & & & \\
\hline
\end{tabular}

Em relação ao trabalho desencadeante da dor:

1. Horas por dia:

2. Jornada: Tempo de intervalo:

Dias por semana:

3. Os sintomas apareceram após quanto tempo na empresa?

4. Tempo de trabalho com o sintoma sem se afastar:

5. Esteve ou está afastado(a) do trabalho? ( ) sim ( ) não Tempo:

6. Atividades realizadas no trabalho: características da atividade \% do tempo precipita sintomas repetitividade esforço físico postura

\begin{tabular}{|c|c|c|c|c|}
\hline n................. & ………........ & 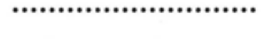 & …………........ & 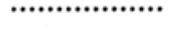 \\
\hline$\cdots$ & …… & ………................ & $\cdots$ & 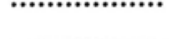 \\
\hline
\end{tabular}

7. Ferramentas:

8. Trocou de função para obter alívio da dor? ( ) sim ( ) não

Melhorou? ( )sim ( ) não Aspectos Especiais

9. Temperatura ambiental: ( ) agradável ( ) quente ( ) fria ( ) ar condicionado

10. Cobre colegas ausentes para manter o ritmo da produção? ( ) sim ( ) não

11. Dobra de turno?

12. Existe um controle rígido da produção?

13. Trabalha em outro emprego?

14. Existe número de empregados suficientes na sua área?

15. Existe algum tipo de prêmio por produtividade?

16. O seu trabalho é estressante?

17. O seu esforço mental é excessivo?

18. Existe alguma atividade doméstica de maior exigência?

( ) $\operatorname{sim}$ ( ) não

( ) $\operatorname{sim}($ ) não

( ) $\operatorname{sim}($ ) não

( ) $\operatorname{sim}($ )não

( ) $\operatorname{sim}($ ) não

( ) $\operatorname{sim}($ ) não

19. Atividade em casa: ( ) lavar ( ) passar ( ) limpeza ( ) cozinhar ( ) outros: 


\section{ANAMNESE:}

1. Queixa e duração:

2. Dor:

( ) não

( ) sim:

3. Local de dor: pedir ao paciente que marque no desenho

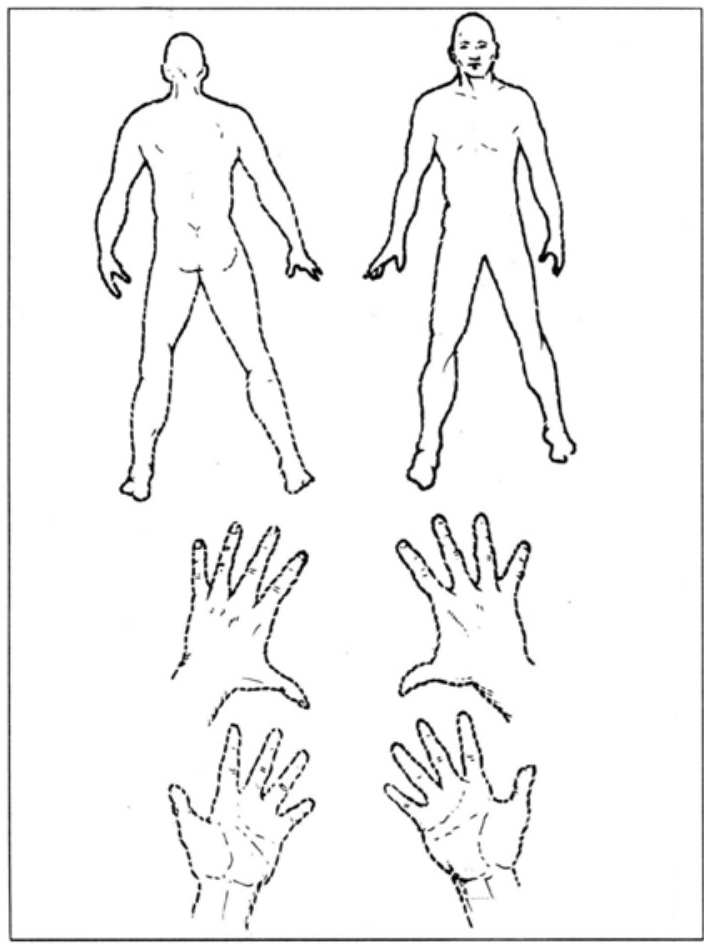

4. Início: ( ) insidioso ( ) súbito ( ) não sabe referir

5. Há quanto tempo que iniciou a dor?

dias

semanas

meses

anos

6. Tipo da dor: ( ) pontada ( ) agulhada ( ) queimor ( ) peso ( ) latejante ( ) choque ( ) fisgada ( ) outros

7. Relação com atividades:

( ) presente antes da atividade

( ) somente durante atividade

( ) piora com atividade

( ) persiste após atividade

( ) presente em repouso

8. Quando ocorre, qual é a duração aproximada? horas dias semanas

9. Peridiocidade da dor:

contínua: ( ) com alteração do padrão cíclica:
( ) com alteração do padrão
( ) aumento da freqüência
( ) aumento da intensidade Período com dor:

( ) sem alteração do padrão ( ) piorando ( ) melhorando

( ) sem alteração do padrão

( ) diminuição da freqüência

( ) diminuição da intensidade Período sem dor: 
10. Fatores de melhora:

( ) repouso ( ) movimentos ( ) mudança tempo ( )frio ( )calor ( )medicação:

11. Fatores de piora:
( ) repouso
( ) movimentos
( ) mudança tempo
( ) frio
( ) calor ( ) ansiedade

12. Intensidade da dor:

VAS $=$

13. Tratamentos prévios:
Resultados:
Resultados:
Resultados:
Resultados:

14. Outros sintomas:
Edema:
Choque:
( ) não ( ) sim:
( ) raro ( ) freqüente
Local:
Câimbra:
( ) não ( ) sim:
( ) raro
( ) freqüente
Local:
Alt.Sensib:
( ) não
( ) raro ( ) freqüente
Local:
Tremores:
( ) não ( ) sim:
( ) raro ( ) freqüente
Local:
Atrofias:
( ) não ( ) sim:
Fraqueza:
( ) não ( ) sim:
( ) raro ( ) freqüente
( ) raro
Local:
( ) raro ( ) freqüente
Local:
Cansaço:
( ) não ( ) não ( ) sim:
( ) raro ( ) freqüente
Local:
Local:

15. Como evoluíram estes sintomas?

\section{Outras alterações:}

1. Sono:

( ) dorme bem sem problemas

( ) Dificuldade: ( ) ocasional

$\mathrm{N}^{2}$ de vezes que acorda à noite:

( ) freqüente ( ) para iniciar o sono

Horas dormidas por noite:

$\begin{array}{llll}\text { Acorda: } & \text { ( ) bem disposto(a) } & \text { ( ) menos cansado(a) ( ) cansado(a) ( ) com dor }\end{array}$

2. Fadiga: ( ) sim ( ) não

3. Humor:
( ) normal
( ) deprimido
( ) ansioso
( ) irritado
( ) estressado
( ) outros

4. AVD e AVP

Pentear o cabelo

Mão no bolso traseiro

Mão nas costas

Amarrar os sapatos

Segurar objetos grandes

Mover os ombros e/ou braços

Girar o pescoço

Inclinar o tronco

Girar a maçaneta da porta

Dificuldade para:
( ) não
( ) não
( ) $\operatorname{sim}$
() $\operatorname{sim}$
( ) não
( ) $\operatorname{sim}$
( ) não
( ) $\operatorname{sim}$
( ) não
() $\operatorname{sim}$
( ) não
( ) $\operatorname{sim}$
( ) não
( ) $\operatorname{sim}$
( ) não
( ) não
() $\operatorname{sim}$
( ) $\operatorname{sim}$
( ) não se aplica
( ) não se aplica
( ) não se aplica
( ) não se aplica
( ) não se aplica
( ) não se aplica
( ) não se aplica
( ) não se aplica
( ) não se aplica 


\begin{tabular}{|c|c|c|c|}
\hline Girar chave & ) não & $\operatorname{sim}$ & ) não se aplica \\
\hline Segurar objetos pequenos & ) não & $\operatorname{sim}$ & não se aplica \\
\hline Lavar louça & ) não & $\operatorname{sim}$ & não se aplica \\
\hline Arear panela & ) não & $\operatorname{sim}$ & não se aplica \\
\hline Lavar roupa & ) não & $\operatorname{sim}$ & não se aplica \\
\hline Estender roupa & não & $\operatorname{sim}$ & não se aplica \\
\hline Passar roupa & ) não & $\operatorname{sim}$ & não se aplica \\
\hline Atender telefone & ) não & $\operatorname{sim}$ & não se aplica \\
\hline Varrer & não & $\operatorname{sim}$ & não se aplica \\
\hline Passar pano no chão & ) não & $\operatorname{sim}$ & não se aplica \\
\hline Limpar Janelas & ) não & $\operatorname{sim}$ & não se aplica \\
\hline Cozinhar & ) não & $\operatorname{sim}$ & não se aplica \\
\hline Aperto de mão & não & $\operatorname{sim}$ & não se aplica \\
\hline Cuidar de Criança & não & $\operatorname{sim}$ & não se aplica \\
\hline
\end{tabular}

\section{INTERROGATÓRIO SOBRE OS DEMAIS APARELHOS}

1. Alterações articulares:

2. Alterações do aparelho locomotor:

3. Alterações neurológicas:

4. Alterações respiratórias:

5. Alterações cardiovasculares:

6. Alterações digestivas:

7. Alterações gênito-urinárias:

8. Alterações endócrinas:

9. Alterações de pele e fâneros:

10. Alterações psiquiátricas:

\section{ANTECEDENTES PESSOAIS:}

1. Já teve fraturas atingindo o membro superior na região afetada?

2. Já teve algum trauma atingindo o membro afetado?

3. Já teve imobilização no membro superior atingido?

4. Já teve diagnóstico prévio de patologia reumática?

5. Já foi submetido a alguma cirurgia?

6. Está tomando algum medicamento?

( ) $\operatorname{sim}$

( ) não Local?

( ) $\operatorname{sim}($ ) não

( ) $\operatorname{sim}($ ) não

( ) $\operatorname{sim}($ ) não

7. Tó () sim () não Qual?

7. Tomou anticoncepcional regularmente por mais de 6 meses? ( ) sim ( ) não

8. Está tomando anticoncepcional atualmente?

9. Possui alguma atividade física regular?

10. Toca algum instrumento?

11. Possui algum hobbie?

12. № de gravidez:

13. Já teve alguma intoxicação?

14. Tem alguma neuropatia?

( ) $\operatorname{sim}($ ) não

\section{HÁBITOS:}
1. Tabagismo
( ) $\operatorname{sim}$
( ) não
2. Etilismo
() $\operatorname{sim}$
( ) não
3. Drogas
( ) $\operatorname{sim}$
Quantos cigarros por dia? Quantas doses por dia?.
Tempo que fuma.
Freqüência:
Freqüência:.
( ) não Tipo:

( ) $\operatorname{sim}$

( ) não Qual?

( ) sim ( ) não Qual?

( ) sim ( ) não Qual?

Quando foi a última gravidez?
( ) $\operatorname{sim}$ ( ) $\operatorname{sim}$ ( ) não 


\section{EXAME FÍSICO:}

1. Estado Geral:

( ) Bom

( ) Regular

( ) Mau

2. Freq.cardíaca:.

Pressão Arterial:.

3. Pulsos periféricos:

4. Psiquismo:

( ) Normal

( ) Alterado:

5. Inspeção:

Postura

Nódulos, gânglios

( ) Normal

( ) Não

Processo inflamatório

( ) Não

Hiperemia

( ) Não

Palidez local

( ) Não

Sudorese

( ) Normal

( ) Alterado:

Deformidades

( ) Não

( ) Alterado:

Trofismo

( ) Normal

Contraturas

Lesões de pele

( ) Não

( ) Não

( ) Alterado:

( ) Alterado:

( ) Alterado:

( ) Alterado:

( ) Alterado:

( ) Alterado:

( ) Alterado:

( ) Alterado:

6. Incapacidade para:
( ) Caminhar ( ) Movimentar-se
( ) Calçar-se
( ) Descalçar-se
( ) Sentar-se ( ) Levantar-se
( ) Despir-se ( ) Vestir-se
( ) Fechar a porta ( ) Higiene
( ) Carregar bolsa

7. Amplitudes de movimentos

COLUNA CERVICAL

COLUNA TORÁCICA

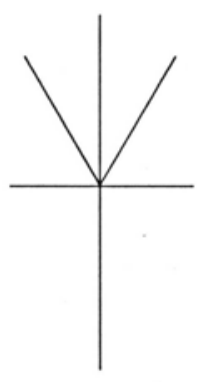

DIREITO

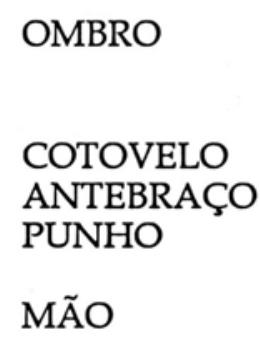

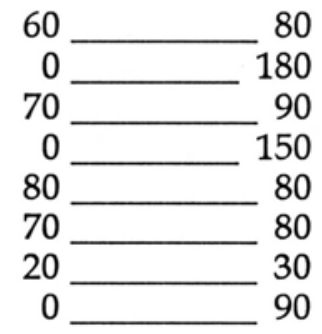

Extensão Adução Rotação Int Extensão Pronação Extensão Desvio rexão Extensão MTC-F

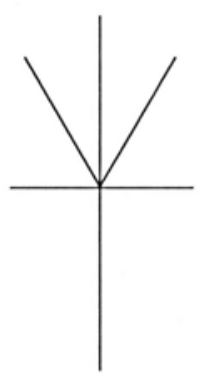

\section{COLUNA LOMBAR}

\section{ESQUERDO}

$60 \square$
$0 \square$
$70 \square$
$0 \square$
$80 \square$
$70 \square$
$20 \square$
150
$0 \square$
80
80
30
90


8. Palpação e testes especiais:

\section{LADO DIREITO}

\section{Palpação de pontos dolorosos miofasciais:}

( ) dor à palpação do m. trapézio superior

( ) dor à palpação do m. esternocleidomastóideo

( ) dor à palpação do m. supra-espinhoso

( ) dor à palpação do m. peitoral maior

( ) dor à palpação do tendão do bíceps do braço

( ) dor à palpação dos $\mathrm{mm}$. flexores do cotovelo

( ) dor à palpação dos $\mathrm{mm}$. extensores do cotovelo

( ) dor à palpação dos mm. extensores do punho

( ) dor à palpação dos mm. flexores do punho

( ) dor à palpação dos $\mathrm{mm}$. intrínsecos da mão

\section{Entesites no cotovelo:}

( ) dor à palpação do epicôndilo medial

( ) dor à palpação do epicôndilo lateral

\section{Patologia nervosa no punho:}

( ) Tinel no túnel do carpo

( ) Tinel no canal de Guyon

\section{Testes especiais:}

( ) Teste de Adson

( ) Teste de Neer

( ) Teste de Jobe

( ) Yergason

( ) Filkestein

( ) Teste de Phalen

( ) Teste de Phalen invertido

( ) Teste de Spurling

( ) Teste de Valsalva

\section{LADO ESQUERDO}

( ) dor à palpação do m. trapézio superior

( ) dor à palpação do m. esternocleidomastóideo

( ) dor à palpação do m. supra-espinhoso

( ) dor à palpação do m. peitoral maior

( ) dor à palpação tendão do bíceps do braço

( ) dor à palpação dos $\mathrm{mm}$. flexores do cotovelo

( ) dor à palpação dos mm. extensores do cotovelo

( ) dor à palpação dos mm. extensores do punho

( ) dor à palpação dos mm. flexores do punho

( ) dor à palpação dos mm. intrínsecos da mão

\section{( ) dor à palpação do epicôndilo medial}

( ) dor à palpação do epicôndilo lateral

( ) Tinel no túnel do carpo

( ) Tinel no canal de Guyon

( ) Teste de Adson

( ) Teste de Neer

( ) Teste de Jobe

( ) Yergason

( ) Filkestein

( ) Teste de Phalen

( ) Teste de Phalen invertido

( ) Teste de Spurling

( ) Teste de Valsalva

9. Exame Neurológico:

Movimentos involuntários

Marcha

Sensibilidade epicrítica

Sensibilidade protopática

Força muscular coluna cervical
( ) não ( ) sim

Descrição:

( ) normal ( ) alterada

Descrição:

( ) normal ( ) alterada

Descrição:

( ) normal ( ) alterada

Descrição:

( ) normal ( ) alterada

Descrição: 


\begin{tabular}{|c|c|}
\hline Força muscular MMII & $\begin{array}{l}\text { ( ) normal ( ) alterada } \\
\text { Descrição:............................. }\end{array}$ \\
\hline Coordenação motora MMSS & $\begin{array}{l}\text { ( ) normal ( ) alterada } \\
\text { Descrição:.............................. }\end{array}$ \\
\hline Reflexos: & DIREITO ESQUERDO \\
\hline
\end{tabular}

Bíceps

Braquiorradial

Tríceps

Estiloradial

Hoffmann

$\mathrm{N}$ (normal)

- (ausente)

$+\quad$ (presente)

$\downarrow$ (hipoativo)

$\uparrow$ (vivo)

$\uparrow \uparrow$ ( exaltado)

EXAMES COMPLEMENTARES:

\begin{tabular}{|c|c|c|c|c|c|c|}
\hline Exame & Data & \multicolumn{5}{|c|}{ Resultados } \\
\hline Hemograma & ........................ & $\begin{array}{l}\mathrm{Hb}= \\
\text { Leuc= } \\
\mathrm{Plaq}=\end{array}$ & $\begin{array}{l}\mathrm{Ht}= \\
\mathrm{N}=\end{array}$ & $\begin{array}{l}\mathrm{VCM}= \\
\qquad \mathrm{Ba}=\end{array}$ & $\begin{array}{r}\mathrm{HCM}= \\
\mathrm{Li}=\end{array}$ & $\begin{array}{r}\mathrm{CHCM}= \\
\mathrm{Eo}=\end{array}$ \\
\hline VHS & ......... $/ \ldots \ldots . . . / \ldots \ldots .$. & & & & & \\
\hline Ácido Úrico & ....................... & & & & & \\
\hline Provas reumáticas & …..../........ & $\begin{array}{l}\text { FR= } \\
\text { Cél LE= } \\
\text { PCR= }\end{array}$ & $=$ & & $\begin{array}{l}\mathrm{WR}= \\
\mathrm{FAN}=\end{array}$ & \\
\hline Radiografia cervical & ........................ & & & & & \\
\hline Radiografia ombro & ....................... & & & & & \\
\hline Radiografia cotovelos & ......................... & & & & & \\
\hline Radiografia de punho e mão & ........................ & & & & & \\
\hline Eletroneuromiografia & .......................... & & & & & \\
\hline $\begin{array}{l}\text { Ultra-sonografia de } \\
\text { partes moles }\end{array}$ & …...................... & & & & & \\
\hline Tomografia computadorizada & .......................... & & & & & \\
\hline Ressonância magnética & ........................ & & & & & \\
\hline
\end{tabular}


ANÁLISE DO POSTO DE TRABALHO QUANTO AO RISCO DE LTC

\begin{tabular}{|c|c|c|}
\hline FATORES & RESULTADOS & $\begin{array}{l}\text { CLASSIFICAÇÃO } \\
\text { A (adequado) M (médio) } \\
\text { E (excessivo) C (crítico) }\end{array}$ \\
\hline 1. Repetitividade & & \\
\hline 2. Força & & \\
\hline 3. Compressão mecânica & & \\
\hline 4. Posturas desfavoráveis dos ombros & & \\
\hline 5. Posturas desfavoráveis dos cotovelos & & \\
\hline 6. Posturas desfavoráveis dos punhos & & \\
\hline 7. Solicitações próprias da tarefa & & \\
\hline 8. Solicitação psicofisiológica & & \\
\hline 9. Solicitações ergonômicas & & \\
\hline 9.1. Posição base & & \\
\hline 9.2. Sobrecarga dorsal & & \\
\hline 9.3. Esforço estático & & \\
\hline 9.4. Vibração & & \\
\hline 9.5. Frio & & \\
\hline
\end{tabular}

\section{CONCLUSÕES FINAIS:}

1. Diagnósticos

D, E, Bilat

\begin{tabular}{l|l}
\hline I & \\
\hline$\overline{I I}$ & \\
\hline$\overline{I I I}$ & \\
\hline $\bar{V}$ & \\
\hline
\end{tabular}

2. Fase Clínica: ( ) I ( ) II ( ) III ( ) IV

3. Prognóstico: ( ) ótimo ( ) bom ( ) reservado ( ) ruim

4. Tratamento:

Medicação:

Cirurgia:

Medidas Físicas:

Cinesioterapia:

Terapia Ocupacional:

Órtese:

Psicologia:

Condicionamento Físico:

Mudança de função:

Afastamento do Serviço:

Outros:

Médico: 


\section{Protocolo de Atendimento na Síndrome Dolorosa Miofascial}

\section{Introduçāo}

A Síndrome dolorosa miofascial (SDMF) se caracteriza por dor e/ou fenômenos autonômicos que são referidos de um ponto gatilho ('trigger') miofascial ativo, com disfunção associada. Os pontos gatilhos são focos hiperirritáveis, geralmente dentro de uma banda tênsil de um músculo esquelético ou de uma fáscia muscular. A causa da Síndrome Dolorosa Miofascial ainda não está completamente esclarecida, porém algumas teorias tentam explicar a fisiopatologia desta doença: 1 . crise metabólica por um consumo energético descontrolado e um suprimento restrito de energia, levando a um ciclo vicioso, culminando com o aparecimento das bandas tênseis, com ou sem pontos gatilhos no seu interior. 2. Fibras musculares denervadas hipersensíveis à acetilcolina levando esta fibra a contraturar-se e formar a banda tênsil. 3. O fenômeno dos pontos gatilhos deve ser a sensibilização de terminações nervosas causadas por um enclausuramento das mesmas dentro das fibras musculares. A importância de se estudar esta síndrome advém do fato dela ser tão comum e muitas vezes extremamente incapacitante, e que somente com o tratamento fisiátrico adequado é que pode-se quebrar este ciclo.
Idade

Sexo

Profissão

Dor

Alterações

autonômicas

Sono

\section{Identificação do Paciente}

Existe uma maior incidência da SDMF nas idades de 20 a 40 anos nas mulheres, e de 30 a 60 anos nos homens.

Não existe diferença entre os sexos, ao contrário do que acontece com a fibromialgia.

É de importância fundamental saber qual a atividade profissional que o indivíduo realiza, pois muitas vezes a persistência da dor é devida a posicionamentos inadequados durante o trabalho, ou excesso de esforço durante o mesmo.

\section{História}

As características da dor na SDMF são: dor surda, pobremente delimitada, a intensidade varia de leve à moderada, situa-se próxima à área gatilho, têm características de dor referida, e pode causar limitação articular. Pode melhorar com repouso, tempo quente e medicação analgésica, antiinflamatória ou antidepressiva. Pode piorar com movimento, com tempo frio e com quadros ansiosos.

Perguntar: lacrimejamento excessivo, secreção nasal, atividade piloeretora, alteração no padrão sudoreico.

$\mathrm{Na}$ SDMF o distúrbio do sono muitas vezes é conseqüência da doença, e deve ser investigado para ser instituída uma terapêutica mais adequada para este problema. Além disto serve como parâmetro para observar se houve melhora da doença após o tratamento.

Assim como o sono, o distúrbio do humor é conseqüência da doença. E também é outro parâmetro para avaliar o tratamento da doença. 
Humor

Incapacidades

Nivel de atividade

Associação com outras patologias
Atividade física regular

Álcool

Tabagismo
Devemos investigar se há qualquer tipo de incapacidade tanto nas AVDs, como nas atividades profissionais ou do lar, e deve ser instituído tratamento específico para cada incapacidade que o indivíduo apresente, com uma equipe multiprofissional.

É o reflexo das incapacidades do doente, e ele deve ser tratado e orientado para retomar sua vida normal.

Importante para podermos inferir uma possível doença de base que possa estar perpetuando o quadro doloroso na SDMF.

\section{Interrogatório sobre demais Aparelhos}

Tentar encontrar algum fator perpetuante:

1. Estresse mecânico:

- assimetria esquelética: encurtamento do membro inferior $(>0,5 \mathrm{~cm}$ já é significativo), hemipelve pequena

- desproporções: segundo osso do metatarso longo, membros superiores longos

- mobiliário inadequado

- postura inadequada

- abuso dos músculos ("oversuse")

- constrição sobre um músculo

- imobilismo

2. Inadequação nutricional:

- Baixos níveis de Vit B1, B6 e B 12, e/ou ácido fólico, e Vit C.

- Adequação de Cálcio, Potássio, Ferro.

- Anemia

3. Doenças metabólicas ou endócrinas:

- hipotireoidismo, hiperuricemia, hipoglicemia.

- insuficiência estrogênica na mulher

4. Fatores psicológicos:

- depressão, tensão causada por ansiedade, Síndrome do "Bom esportista" (indivíduo que nega as doenças, não usa medicamentos, pratica excesso de exercícios), aspectos comportamentais.

5. Infeç̧ões e infestações crônicas:

- virais (gripes, herpes simples), giardíase, amebíase

6. Outros:

- rinite alérgica, distúrbio do sono e síndromes nervosas periféricas comportamentais

\section{Hábitos}

A SDMF pode ser causada tanto por "overuse" como por imobilismo, por isto é importante caracterizar em que extremo o doente pode se encontrar:

Pode estar associada com distúrbios nutricionais

Pode estar associado com deficiência de Vit C 
Cirurgias prévias

Tireoidopatia

Deficiência

estrogênica

Diabetes

Gestações

Peso, altura

Avaliação objetiva das incapacidades

Inspeção

Limitações articulares

\section{Antecedentes}

A fibrose e a cicatriz que se forma pode predispor ao surgimento de pontos gatilhos, e levar à dor miofascial.

O hipotireoidismo está associado com a perpetuação da SDMF.

A menopausa, ooforectomia ou qualquer causa que leve a um rebaixamento no nível dos estrógenos está relacionada com a perpetuação da SDMF, e se não tratar adequadamente este problema será mais difícil conseguir bons resultados com o tratamento.

Períodos de hipoglicemia são prejudiciais para o metabolismo muscular e podem perpetuar os pontos gatilhos.

A gravidez aumenta muito as necessidades de ácido fólico.

\section{Exame Físico}

Importantes parâmetros para avaliar massa corpórea e proporções.

É importante observar o doente e anotar suas incapacidades frente a tarefas simples, como parâmetros de evolução.

Procurar por: assimetrias, discrepâncias, escoliose, cifose, sinais inflamatórios (artrites, bursites, epicondilites) etc.

São muito importantes para avaliarmos: gravidade da doença, segmentos acometidos e evolução do tratamento.

Os gráficos para anotar os movimentos da coluna devem seguir a padronização:

- para dor: + dor leve que não impede o movimento

++ dor moderada que não impede o movimento

+++ muita dor que não impede o movimento

++++ limitação importante do movimento por dor forte

- para limitação: 0 se estiver normal

-1 se houver limitação ao movimento de apenas $25 \%$

-2 se houver limitação ao movimento de $50 \%$

-3 se houver limitação ao movimento de $75 \%$

-4 se houver limitação ao movimento totalmente

Exemplo: paciente tem limitação para flexão e lateralização da coluna cervical em $50 \%$ e para a extensão em $25 \%$ e rotação normal. Sente pouca dor para os movimentos de rotação, extensão e flexão e muita dor aos movimentos de lateralização:

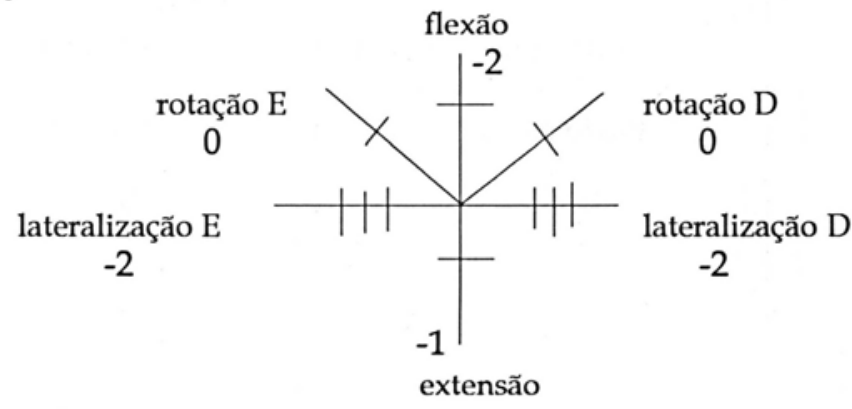


Exame Neurológico

Testes de força e deficiência muscular

Exame Muscular

Hemograma

Uréia, Creatinina, $\mathrm{Na}, \mathrm{K}, \mathrm{P}$

\section{Glicemia}

Fator Reumatóide Prova de WaalerRose e Fator AntiNúcleo

VHS, mucoproteínas
Quanto às limitações de outras articulações fora do eixo da coluna, deve-se anotar a limitação da Amplitude de Movimento que foi observada.

Algumas vezes a SDMF pode estar sendo perpetuada por uma compressão de um nervo periférico (síndromes compartimentais), radiculopatia etc, e que devem ser tratadas.

Estes testes visam avaliar se os músculos estão com o grau de força normal ou se estão com alguma fraqueza: manobras deficitárias (Mingazzini, Barré. Raimiste), teste manual de força, provas específicas para alguns músculos:

- Teste de Kraus-Weber: para força e endurance dos músculos abdominais. E também pode ser feito para flexibilidade da coluna lombar.

- Teste de R. Mackenzie: para deficiência em flexão e extensão da coluna lombar.

Esta é a parte mais importante no manuseio do paciente com dor miofascial, pois da palpação dos músculos, bandas tênseis e pontos gatilhos é que vem o diagnóstico e o tratamento adequado.

O exame do sistema músculo-fascial se inicia pelo posicionamento do paciente e relaxamento do mesmo. A seguir deve-se fazer a palpação das bandas tênseis e de seus pontos gatilhos, iniciando com uma palpação com a mão empalmada para se ter uma noção do tônus e aderências ao subcutâneo. E em seguida se inicia a palpação em pinça, quando uma banda é identificada ela deve ser explorada ao longo do seu comprimento para localizar-se o ponto de maior dolorimento, é o ponto gatilho.

Ainda na palpação deve-se observar a resposta "twitch" e o sinal do 'Jump". A resposta "twitch" se caracteriza por um salto de uma porção do músculo quando este é estimulado por toque ou agulha. O sinal do "Jump" ocorre quando uma pressão é aplicada em um ponto gatilho ativo e se observa um pulo do paciente.

Após este exame deve-se registrar:

- "trigger points": pontos gatilhos (com área de dor referida à distância)

- "tender points": pontos dolorosos (área de dor sobre o ponto)

- área de dor referida

- para cada ponto (gatilho ou doloroso) deve-se fazer a dolorimetria (ou a escala visual analógica para dor - VAS)

- anotar a evolução dolorimétrica de cada ponto e o surgimento de novos pontos dolorosos, se houverem, em cada retorno.

\section{Exames Complementares}

Avaliar anemia, sinais de infecção, coagulopatia (hepatopatia, def. Vitamínica).

Avaliar função renal, distúrbios hidroeletrolíticos.

Avaliar a presença de hipoglicemia ou diabetes.

Avaliar a existência de problemas reumatológicos.

Avaliar se existe indícios de inflamação ou infecção. 
T3, T4, TSH

Creatinofosfoquinase

Ácido Úrico

Urina

Fezes

Radiografia simples

Ultra-sonografia, tomografia computadorizada, ressonância magnética

Eletroneuromiografia

Cintilografia óssea

Densitometria Óssea

Medicação

Meios físicos

Cinesioterapia

Agulhamento seco

Agulhamento $e$ infiltração
Avaliar a função tireoideana, principalmente se há hipotireoidismo.

Afastar miosites ou miopatias.

Avaliar se existe hiperuricemia.

Avaliar função renal, indícios de infecção.

Avaliar se existe parasitoses ou infestações.

Avaliar se existe: osteoporose, fraturas, deslocamentos, artroses, discrepâncias etc.

Para avaliar se existe alguma doença orgânica subjacente tratável.

Avaliar presença de mielopatias, radiculopatias, neuropatias ou miopatias.

Identificar locais de prováveis focos de doença: inflamatória, neoplásica ou destruição tecidual.

Avaliar se existe osteoporose.

\section{Tratamento}

Pode ser instituída terapêutica analgésica, antiinflamatória não hormonal ou hormonal, relaxantes musculares, ansiolíticos ou antidepressivos.

Com o intuito de melhorar a dor, contraturas e limitação do movimento pode-se instituir qualquer meio físico de calor superficial ou profundo, hidroterapia, eletroterapia, massoterapia ou mecanoterapia. No entanto os mais utilizados são a massagem, ultra-som e estimulação elétrica.

Várias técnicas podem ser utilizadas, citaremos algumas delas:

- Cinesioterapia convencional

- "Spray" e alongamento (Travell e Simons)

- "Spray" e relaxamento (Kraus)

- "IRS": Post Isometric relaxation, Reciprocal Inhibition and Stretch, ou seja: Relaxamento Pós-exercício isométrico, Inibição Recíproca e Alongamento (Fischer)

OBS: O "Spray" empregado é um resfriante da pele à base de etilclorida.

Estimulação do ponto gatilho com agulha apropriada, sem infiltração de qualquer substância.

A técnica inclui o efeito mecânico da agulha e o efeito farmacológico do anestésico local. Vários tipos de agulhamento e infiltração podem ser empregados:

1. Injeção do ponto gatilho

- agulhamento e infiltração concentrado somente no ponto gatilho

- agulhamento e infiltração no ponto gatilho e na banda tênsil, na junção miotendínea e na inserção aos ossos. 
Psicoterapia

Reposição hormonal

Mudanças comportamentais

VAS

Queixa

Incapacidades

Medicação
- injeção de esteróide

2. Agulhamento e infiltração do tecido lesado e sensibilizado (tender) nos casos de entorses, luxações, traumas esportivos, lesão por esforço repetitivo ou "overuse".

3. Bloqueios somáticos para aliviar espasmo muscular

4. Agulhamento e infiltração de áreas gatilho que geram espasmo muscular e pontos gatilhos: entorses de ligamentos, bursites etc.

5. Bloqueios nervosos:

- bloqueio pré-infiltração para reduzir a dor do agulhamento em uma área muito sensível.

Fazer um "coating" (casaco anestésico) ao redor da área dolorosa que vai ser infiltrada

Para pacientes com componentes ansiosos ou depressivos

Estrógenos ou hormônios tireoideanos

É importante assinalar: atividade esportiva, recreação, lazer, hábitos (tabagismo, etilismo, drogas)

\section{Evoluçāo}

Nos retornos avaliar o VAS (Escala Visual Analógica) em relação a área tratada na consulta anterior.

Sempre avaliar se o doente não retorna com as "mesmas queixas", porém a sua área dolorosa não é mais a anteriormente referida e sim uma nova área que surgiu em decorrência de um esforço que ele realizou quando se sentiu melhor.

Também indagar sobre freqüência e duração dos surtos de dor, e o quanto esta dor está afetando as atividades deste doente: sono, humor, AVD, Profissional, no lar, esporte e lazer.

Freqüência do uso dos analgésicos prescritos "se necessário".

Aderência ao tratamento medicamentoso proposto na primeira consulta.

Efeitos colaterais e adversos dos diferentes medicamentos em uso. Atenção com as Interações Medicamentosas.

\section{Avaliaçāo Final:}

Avaliação dos principais parâmetros da dor e de suas implicações na vida do indivíduo.

No exame muscular deve-se fazer uma mensuração objetiva de cada ponto gatilho que foi tratado (dolorimetria ou VAS), para ficar arquivado como dados objetivos do tratamento.

\section{Critérios Diagnósticos para SDMF}

(D. G. Simons, 1991, modificado por A. A. Fischer)

\section{Critérios Maiores}

- Dor localizada em uma região, geralmente unilateral, e um grau de dolorimento assimétrico.

- Palpação de uma banda tênsil em um músculo que é acessível

- Dor em uma zona referida conhecida de um ponto gatilho (nem sempre presente, freqüentemente a dor é na mesma área do ponto doloroso) 
- Foco de sensibilidade em um ponto ao longo de todo o comprimento de uma banda tênsil

- Músculo tenso à palpação, possivelmente esta seja a causa da limitação do movimento.

Critérios menores:

- Reprodutibilidade da queixa dolorosa ou alteração da sensação através da pressão sobre o ponto gatilho

- resposta "twitch" da banda tênsil alívio da dor pelo alongamento do músculo ou por injeção no ponto doloroso

\section{Conclusōes}

Em primeiro lugar deve-se fazer um diagnóstico preciso da SDMF. A modalidade terapêutica mais eficiente para alívio imediato da dor é agulhamento e infiltração com lidocaína para quebrar e dessensibilizar o tecido anormal que causa a dor. Mas a infiltração é apenas o primeiro passo, pois ainda deve se seguir a estimulação elétrica, e/ou "spray" e alongamento, e cinesioterapia para inativar os pontos remanescentes. A causa e os fatores perpetuantes da doença devem ser identificados, tratados e removidos para evitar a recorrência da doença.

\section{Referências Bibliográficas}

1. BONICA, J.J. - The Management of Pain, Philadelphia, Lea \& Febiger, 1990.

2. FISCHER, A.A. - Differential Diagnosis of Muscle Tenderness and Pain, Pain Management, 30 36. 1991.

3. FISCHER, A.A. - Diagnosis and management of chronic pain in physical medicine and rehabilitation. IN: RUSKIN AP, Current Therapy in Physiatry. Philadelphia. WB Saunders, 123-145, 1984.

4. FISCHER, A.A. - Documentation of Myofascial trigger points, Arch Phys Med Rehabil, 69: 286291, 1988.

5. KRAUS, H. - Clinical Treatment of Back and Neck Pain. New York, McGraw Hill, 119, 1970.

6. KRAUS, H. - Diagnosis and Treatment of Muscle Pain, Chicago, Quintessence Publishing Co, 1988.

7. KRAUS, H.; FISCHER, A.A. - Diagnosis and treatment of myofascial pain. The Mount Sinai Journal of Medicine 58:235-239, 1991.

8. MCKENZIE, R.A. - The Lumbar Spine, Mechanical Diagnosis and Therapy. New Zealand: Spinal Publications, 1981

9. SIMONS, D.G. - Referred phenomena of myofascial trigger points. New Trends in Referred Pain and Hyperalgesia, Cap 28. № 27 in the series Pain Research and Clinical Management. Elsevier science Publishers, Amsterdam, 341-457. 1993.

10. TRAVELL, J.G.; SIMONS, D.G. - Myofascial Pain and Dysfunction: The Trigger Point Manual, Vol 1. Willians \& Wilkins, Baltimore, 1983.

11. TRAVELL, J.G.; SIMONS, D.G. - Myofascial Pain and Dysfunction: The Trigger Point Manual, Vol 2. Willians \& Wilkins, Baltimore, 1992.

12. HONG, CHANG-ZERN - Lidocaine injection versus dry needling to myofascial trigger point. Am J Phys Med and Rehab 73:256-263, 1994. 


\section{Protocolo de Atendimento na Síndrome Dolorosa Miofascial}

\section{IDENTIFICAÇÃO}

Nome:

Idade:

Sexo:

Estado civil:
Raça:
)branca
( )negra
( )amarela
( )vermelha

Profissão:

Endereço:

Cidade:

Telefone:

\section{HISTÓRIA}

\section{Anamnese:}

Queixa e duração:

Tratamentos e resultados:

Características da dor:

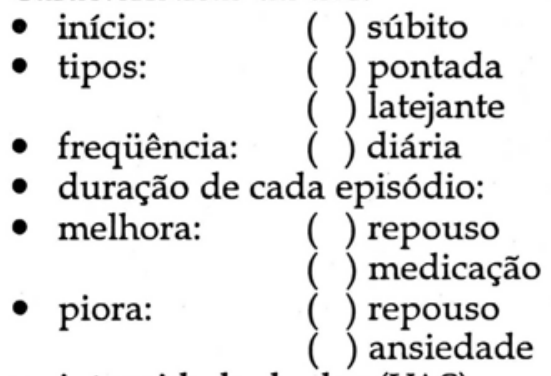

- intensidade da dor (VAS):

( ) insidioso
( ) agulhada
( ) phoque
por semana
(.... horas
() movimento
() outros
( ) outros

( ) após trauma

( ) queimor

( ) fisgada

( ) por mês

..... dias

( ) mudança de tempo ( ) frio

( ) mudança de tempo ( ) frio quando está mais forte

( )outros:

( ) por ano

.... semanas

Sintomas autonômicos:
Sono:
Humor:
( ) normal

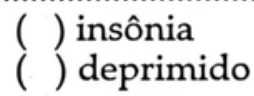
( ) hipersonia
ansioso
( ) acorda cansado(a)

( ) outros

( ) peso ( ) formigamento

..... meses

( ) calor

( ) calor

Incapacidades para:

- AVD:

- Profissional:

( ) sem incapacidades ( ) incapacidade parcial

() sem incapacidades

( ) incapacidade parcial

- Atividades no lar:

) incapacidade parcial

( ) incapacidade total
( ) incapacidade total
incapacidade total

Nível de Atividade:

$\begin{array}{ll}\text { - trabalho: } & \text { ( )normal } \\ \text { - esporte: } & \text { ( )normal } \\ \text { - lazer: } & \text { ( )normal }\end{array}$

( )pouco afetado
( )pouco afetado
( )pouco afetado

( )muito afetado

( )muito afetado

( )muito afetado

( ) afastado
( )afastado
( )afastado

A dor está relacionada com alguma outra patologia:
( ) inflamatória
( ) infecciosa
( ) tumoral
( ) endócrina
( ) degenerativa
( ) alteração mecânica
( ) metabólica
trauma
( ) outros. 


\section{INTERROGATÓRIO SOBRE DEMAIS APARELHOS:}

- Neurológico:

- Otorrinolaringológico:

- Endócrino:

- Digestivo e nutricional:

- Cardiovascular:

- Pulmonar:

- Urogenital:

- Pele e fâneros

\section{HÁBITOS:}

- atividade física regular:

- álcool:

- tabagismo:

ANTECEDENTES:

- cirurgias prévias:

- doença de tireóide:.

- menopausa:

- Fez ou faz reposição hormonal com estrógenos:

- diabetes:

EXAME FISICO:

\section{Geral:}

- peso:........... Kg altura:.......... $\mathrm{m}$

\section{Especifico:}

\section{Dificuldade para:}

Limitações articulares:

- coluna: cervical

$$
\begin{aligned}
& \text { ( ) caminhar } \\
& \text { ( ) vestir-se }
\end{aligned}
$$

( ) sentar-se
( ) calçar-se

( ) levantar-se

dorsal

lombar
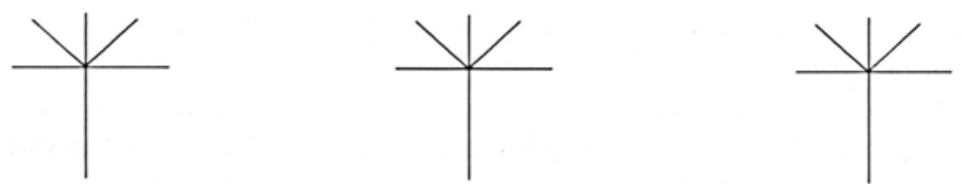

pulso:.

bpm PA:

$x$

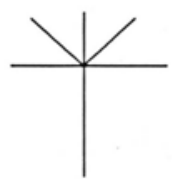

- articular:

ombro D

cotovelo D

punho D.

mão D

$\mathrm{mmHg}$

quadril D

joelho D

tornozelo D

pé $\mathrm{D}$

( ) movimentar-se

Exame neurológico:

Força muscular:

ombro E

cotovelo E

punho E.

mão $\mathrm{E}$

quadril E

joelho $\mathrm{E}$.

tornozelo $\mathrm{E}$

pé E 


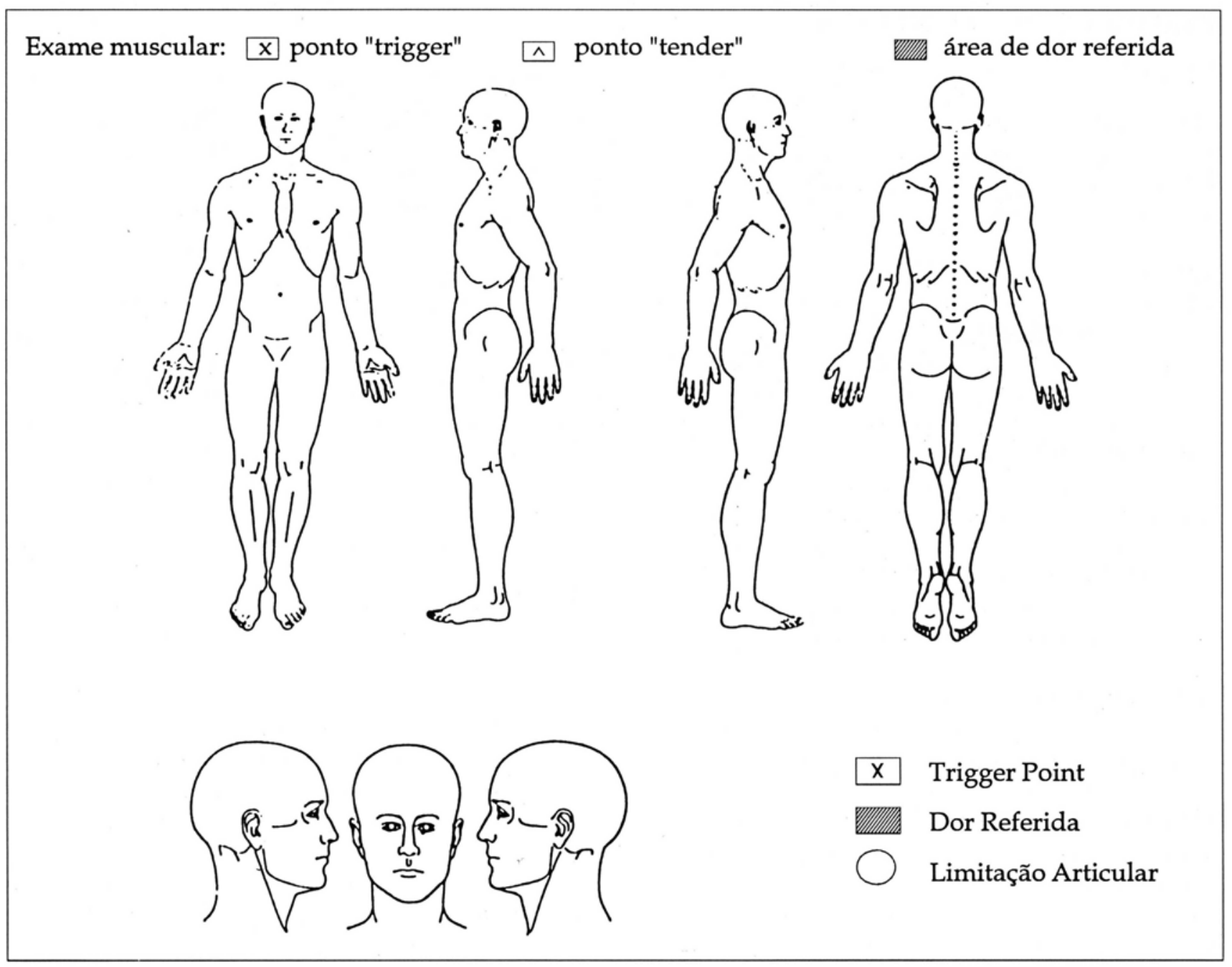

\begin{tabular}{|c|c|c|c|c|c|c|}
\hline Pontos & $\begin{array}{c}\text { Data da } \\
1^{\mathrm{a}} \text { Consulta }\end{array}$ & $\begin{array}{c}\text { Dolorímetro } \\
\text { ou VAS }\end{array}$ & $\begin{array}{c}\text { Data } \\
1^{\circ} \text { retorno }\end{array}$ & $\begin{array}{c}\text { Dolorímetro } \\
\text { ou VAS }\end{array}$ & $\begin{array}{c}\text { Data } \\
2^{\mathrm{Q}} \text { retorno }\end{array}$ & $\begin{array}{c}\text { Dolorímetro } \\
\text { ou VAS }\end{array}$ \\
\hline $\mathrm{N}^{2}$ & 1 & & / / & & / & \\
\hline$\overline{\mathrm{N}^{2}}$ & 1 & & 1 & & 1 & \\
\hline $\mathrm{N}^{2}$ & 1 & & 1 & & 1 & \\
\hline$\overline{\mathrm{N}^{2}}$ & 1 & & 1 & & 1 & \\
\hline No & 1 & & 1 & & 1 & \\
\hline$\overline{\mathrm{N}^{2}}$ & 1 & & 1 & & 1 & \\
\hline $\mathrm{N}^{2}$ & 1 & & 1 & & 1 & \\
\hline $\mathrm{N}^{\mathrm{O}}$ & 1 & & 1 & & 1 & \\
\hline$\overline{\mathrm{N}} \mathbf{2}$ & 1 & & 1 & & 1 & \\
\hline$\overline{\mathrm{N}^{2}}$ & 1 & & 1 & & 1 & \\
\hline$\overline{\mathrm{N}} \mathrm{o}$ & 1 & & 1 & & 1 & \\
\hline$\overline{\mathrm{N}^{0}}$ & 1 & & 1 & & 1 & \\
\hline No & 1 & & 1 & & 1 & \\
\hline$\overline{\mathrm{N}^{2}}$ & 1 & & 1 & & 1 & \\
\hline$\overline{\mathrm{N} N}$ & 1 & & 1 & & 1 & \\
\hline № & 1 & & 1 & & 1 & \\
\hline
\end{tabular}




\section{EXAMES COMPLEMENTARES:}

\section{Sangue:}

\begin{tabular}{|c|c|c|c|c|c|}
\hline $\mathrm{Hb}: \ldots \ldots \ldots \ldots . . . . . . . .$. & 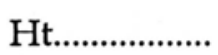 & Leuc: ................. & Neutr: ................. & 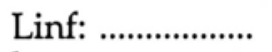 & $\mathrm{q}: \ldots \ldots \ldots \ldots \ldots$ \\
\hline 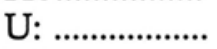 & ............ & 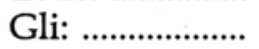 & Na: ......................... & $\ldots \ldots \ldots$. & \\
\hline FR: .................. & WR: ................ & FAN: ...................... & VHS: ........................ & Muco: ................... & \\
\hline T3: ........................ & T4: ...................... & TSH: ...................... & CPK: ...................... & Ac U: .................... & \\
\hline
\end{tabular}

Urina:

Fezes:

Radiografia simples:

\section{Ultra-sonografia:}

\section{Tomografia computadorizada:}

\section{Ressonância magnética:}

\section{Eletroneuromiografia:}

\section{Cintilografia óssea:}

\section{Densitometria óssea:}

\section{TRATAMENTO PROPOSTO :}

- Medicação:

- Meios físicos:

- Cinesioterapia:

- Agulhamento seco:

- Agulhamento e infiltração:

- Psicoterapia:

- Reposição hormonal:

- Mudanças comportamentais: 
EVOLUÇÃO:

\begin{tabular}{|c|c|c|c|c|}
\hline & 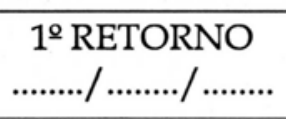 & modificações & 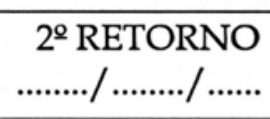 & modificações \\
\hline \multicolumn{5}{|l|}{ VAS } \\
\hline \multicolumn{5}{|l|}{ Queixa principal } \\
\hline \multirow{2}{*}{\multicolumn{5}{|c|}{$\begin{array}{l}\text { Incapacidades } \\
\text { Medicação }\end{array}$}} \\
\hline & & & & \\
\hline \multicolumn{5}{|l|}{ Meios físicos } \\
\hline \multicolumn{5}{|l|}{ Cinesioterapia } \\
\hline \multicolumn{5}{|l|}{ Agulhamento seco } \\
\hline \multicolumn{5}{|l|}{ Agulhamento e infiltração } \\
\hline \multicolumn{5}{|l|}{ Psicoterapia } \\
\hline Reposição hormonal & & & & \\
\hline Mudanças comportamentais & & & & \\
\hline
\end{tabular}

\section{AVALIAÇÃO FINAL:}

Quanto à dor:

- local, duração, períodos de melhora e piora, tipo:

- VAS: quando está mais forte .agora

- Sono:

- Humor:

- incapacidades para: AVD ( ) sem incapacidade profissional ( ) sem incapacidade atividades no lar ( ) sem incapacidade ( ) incapacidade parcial ( ) incapacidade parcial ( ) incapacidade parcial
( ) incapacidade total

( ) incapacidade total

( ) incapacidade total

- nível de atividade:
trabalho
( ) normal
( ) pouco afetado
( ) muito afetado
( ) afastado
esporte
( ) normal
( ) pouco afetado
( ) muito afetado
( ) afastado
lazer
( ) normal
( ) pouco afetado
( ) muito afetado
( ) afastado

\section{Exame físico:}

Incapacidades para: ( ) caminhar $\quad$ ( ) sentar-se

- Limitações articulares

coluna: cervical

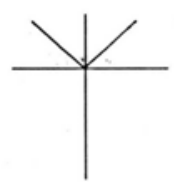

dorsal

lombar
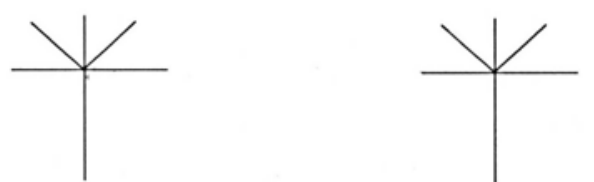

articular:

- Exame neurológico:

- Exame muscular: 


\section{Protocolo de Atendimento nos Problemas Músculo-esqueléticos em Hemofilia}

\section{Introdução}

A hemofilia é doença que se manifesta por episódios hemorrágicos, podendo ocorrer em qualquer localização do organismo após trauma, espontaneamente ou após pequenos traumas não referidos. Estudos mostram que o sistema osteoarticular sofre $83,3 \%$ dos episódios hemorrágicos em um hemofílico, e das articulações acometidas o joelho é a mais afetada $(85,5 \%)$, seguido pelo cotovelo $(49,0 \%)$, tornozelo $(37,7 \%)$, quadril (21,6 \%) e ombro (16,9 \%).

Em decorrência desses fatos, incide sobre o paciente portador de hemofilia, possibilidade muito elevada de que, ao longo dos anos, em decorrência dessas hemorragias, venha a desenvolver incapacidade. Este protocolo tem como finalidade promover avaliações periódicas, e facilitar a visualização da situação de cada paciente hemofílico, ao longo do tempo.

Este protocolo é composto de vários itens:

- identificação

- diagnósticos

- exame físico

- escore clínico: para pontuar o estado clínico em que se encontra o paciente.

- escore radiológico: para pontuar o estado radiológico.

- resumo das avaliações: acompanhar ao longo do tempo a evolução do paciente, de modo rápido e fácil. Além dos dados obtidos no protocolo, o resumo contém uma série de procedimentos que complementam os dados referentes ao aparelho locomotor e que nos permitem visão mais completa do nosso paciente.
Data das Avaliações

Inibidor

Fator

Hemartroses

\section{Identificaçāo}

O protocolo será aplicado a cada 6 meses, devendo o paciente ser convocado, especialmente para esta finalidade.

\section{Diagnósticos}

O protocolo deverá ser aplicado a todos os pacientes portadores de hemofilia A ou B ou portadores da doença de von Willebrand.

Aplica-se o protocolo na ausência de episódios hemorrágicos agudos, com intuito de evitar a obtenção de falsos resultados.

\section{História}

É importante destacar a presença ou ausência de inibidor, já que às vezes a resposta não safisfatória de alguns casos submetidos a tratamento pode estar ligada a sua presença, fato esse que irá alterar a conduta do tratamento hematológico e as oportunidades reabilitativas.

É importante registrar o uso do Fator, periodicidade para uso do mesmo e local habitual para sua utilização.

Quanto à localização, caracterização (leves ou moderadas), freqüência com que estas ocorreram nos últimos 6 meses e provável fator etiológico. 
Hemorragias

musculares

Hemorragias de Subcutâneo

ADM

Escore Clínico
Leve:

- dor de pequena intensidade

- ligeiro aumento de volume

- leve restrição da mobilidade

- regride em 24 horas, com uso de fator

\section{Moderada}

- dor intensa

- grande aumento de volume

- limitação funcional

- não regride em 24 horas, apesar do uso do fator

Evidenciar a presença ou não de comprometimento nervoso periférico e caracterizando-as, também, em leves e moderadas, segundo critérios definidos, levantando o provável agente causal.

Embora menos freqüentes (19,1 \%), merecem atenção, já que as localizações habituais não favorecem a reabsorção do sangue extravasado, havendo o risco de complicações.

\section{Exame Físico}

Para estes pacientes é importante avaliar as condições gerais, condições para a deambulação, atrofias musculares, comprometimento articular e deformidades

As amplitudes de movimentos das principais articulações acometidas devem ser anotadas. Os ângulos de movimentos normais estão mostrados, e as mensurações obtidas devem seguir esta padronização em todas as aplicações do protocolo, para podermos comparar os resultados obtidos.

Serão avaliadas as articulações do joelho, cotovelo, tornozelo, quadril e ombro, bilateralmente, segundo subitens existentes e numerados de 1 a 8 , à esquerda do quadro.

A deformidade axial será medida apenas no joelho e tornozelo e a contratura em flexão será considerada apenas para o joelho, tornozelo e quadril.

A pontuação que será dada a cada item deverá obedecer aos critérios especificados.

O valor encontrado para cada item será transportado para o campo correspondente à articulação em questão, observando-se o lado avaliado (direito ou esquerdo).

O subitem TOTAL corresponde à somatória dos pontos obtidos para a articulação em estudo.

A pontuação do Escore Clínico irá variar de 0 (zero), que representa articulação normal, a 14 (quatorze), que representa articulação gravemente acometida, no caso do joelho e tornozelo. Para os casos do cotovelo e ombro o máximo da articulação gravemente acometida é 10 (dez), e para o quadril, o máximo é 12 (doze).

Serão avaliadas as articulações do joelho, cotovelo, tornozelo, quadril e ombro, bilateralmente, segundo os subitens que se encontram à esquerda do quadro e são numerados de 1 a 8 .

Os critérios para se estipular o número de pontos destinados a cada articulação encontram-se no quadro.

O valor encontrado para cada item será transportado para o campo 
correspondente à articulação e o lado (direito ou esquerdo) em estudo.

O subitem TOTAL correspondente à somatória dos pontos conferidos a cada item e que configuram a situação da articulação naquele momento.

A pontuação do Escore Radiológico irá variar entre 0 (zero) que corresponde à articulação normal e 13 (treze), que corresponderá à articulação gravemente comprometida do ponto de.vista radiológico.

\section{Resumo das Avaliaçōes}

Com o intuito de facilitar a visualização da evolução do paciente este quadro deve ser preenchido a cada avaliação.

O espaço de distribuição topográfica é usado para desenhar o estado atual do paciente, segundo a legenda:

$\square=$ atrofia muscular

$\mathrm{O}=$ articulações comprometidas

= $=$ deformidades

A possibilidade de congregar em um mesmo quadro dados referentes a procedimentos hematológicos, odontológicos, de reabilitação e ortopédicos, facilita a visualização da situação do paciente hemofílico, como um todo, podendo-se ainda confrontar esses dados em datas sucessivas com grande rapidez e objetividade.

A análise seqüencial destes dados nos permitirá inferir sobre o sucesso terapêutico do ponto de vista do suporte hemoterápico utilizado, bem como das medidas reabilitativas empregadas. Ao mesmo tempo pode-se observar o grau de aderência aos demais aspectos terapêuticos envolvidos na assistência multidisciplinar do paciente hemofílico.

\section{Referências Bibliográficas}

1. BATTISTELLA, L.R.; LOURENÇO, C.; RIBEIRO SOBRINHO, J.B. - Reabilitação em Hemofilia, IN Medicina de Reabilitaçāo, Lianza S, cap 23, Guanabara Koogan, Rio de Janeiro, 1983.

2. LOURENÇO, C.; SANTOS, C.A.; BATTISTELLA, L.R. - Protocolo de Avaliação em Hemofilia, Boletim, vol XV, 162:30-43, 1993. 


\section{Protocolo de Atendimento nos Problemas Músculo-esqueléticos em Hemofilia}

\section{IDENTIFICAÇÃO}

Nome:

Idade: Sexo: Estado civil: Raça: ( )branca ( )negra ( )amarela ( )vermelha

Endereço:

Cidade:.

Nome da mãe:

Procedência remota/atual:

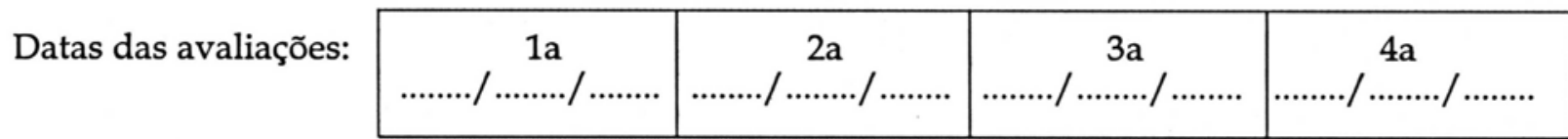

\section{DIAGNÓSTICOS}
( ) hemofilia A
( ) hemofilia B
( ) von Willebrand
( ) Outros
( ) leve ( $>5 \%$ )
( ) moderada (1 a $5 \%$ )
( ) grave (<1\%)

Taxa de fator:

Inibidor:

\begin{tabular}{|l|c|c|c|c|c|}
\hline Consulta & $1 \mathrm{a}$ & $2 \mathrm{a}$ & $3 \mathrm{a}$ & $4 \mathrm{a}$ \\
\hline Presente (+) & Ausente (-) Não sabe informar (NI) & & & & \\
\hline
\end{tabular}

Modo habitual de manutenção (de tratamento)

Consulta

Não faz uso de fator

Faz uso de fator raramente

Faz uso de fator nos episódios hemorrágicos

Faz uso de fator profilaticamente

\begin{tabular}{|c|c|c|c|c|}
\hline $1 a$ & $2 a$ & $3 a$ & $4 a$ \\
\hline & & & \\
\hline & & & \\
\hline & & & \\
\hline
\end{tabular}

Habitualmente faz uso de:

\begin{tabular}{|l|c|c|c|c|}
\hline Consulta & $1 \mathrm{a}$ & $2 \mathrm{a}$ & $3 \mathrm{a}$ & $4 \mathrm{a}$ \\
\hline Crioprecipitado () Liofilizado (L) & & & & \\
\hline
\end{tabular}

Quando necessária a reposição de fator, recorre a:

\begin{tabular}{|c|c|c|c|c|}
\hline \multirow{2}{*}{\multicolumn{5}{|c|}{$\begin{array}{l}\text { Consulta } \\
\text { Hospital da rede pública }\end{array}$}} \\
\hline & & & & \\
\hline Hospital da rede privada & & & & \\
\hline Banco de Sangue & & & & \\
\hline Entidade para atendimento do hemofílico & & & & \\
\hline Programa domiciliar & & & & \\
\hline
\end{tabular}

Quanto às hemartroses

\begin{tabular}{ll|c|c|c|c|}
\hline Consulta & $1 \mathrm{a}$ & $2 \mathrm{a}$ & $3 \mathrm{a}$ & $4 \mathrm{a}$ \\
\hline Presente (+) Ausente (-) & & & & \\
\hline
\end{tabular}


Articulações envolvidas:

\begin{tabular}{|l|l|l|l|l|l|l|l|l|}
\hline Consulta & \multicolumn{2}{|c|}{ 1a } & \multicolumn{2}{|c|}{ 2a } & \multicolumn{2}{|c|}{ 3a } & \multicolumn{2}{c|}{ 4a } \\
\hline Direito (D) Esquerdo (E) & D & E & D & E & D & E & D & E \\
\hline Joelho & & & & & & & & \\
\hline Cotovelo & & & & & & & & \\
\hline Tornozelo & & & & & & & & \\
\hline Quadril & & & & & & & & \\
\hline Ombro & & & & & & & & \\
\hline Outros & & & & & & & & \\
\hline
\end{tabular}

Freqüência das hemartroses, tipos e características (anotar, no quadro o número de episódios)

\begin{tabular}{|c|c|c|c|c|c|c|c|c|c|c|c|c|c|c|c|c|}
\hline & \multicolumn{4}{|c|}{$1 \mathrm{a}$} & \multicolumn{4}{|c|}{$2 a$} & \multicolumn{4}{|c|}{$3 a$} & \multicolumn{4}{|c|}{$4 a$} \\
\hline \multirow{2}{*}{$\begin{array}{l}\text { Direito (D) Esquerdo (E) } \\
\text { Leve (L) Moderado (M) }\end{array}$} & \multicolumn{2}{|c|}{$\bar{D}$} & \multicolumn{2}{|c|}{$\mathrm{E}$} & \multicolumn{2}{|c|}{ D } & \multicolumn{2}{|c|}{$\bar{E}$} & \multicolumn{2}{|c|}{$\bar{D}$} & \multicolumn{2}{|c|}{$\mathrm{E}$} & \multicolumn{2}{|c|}{$\bar{D}$} & \multicolumn{2}{|c|}{$\mathrm{E}$} \\
\hline & $\mathrm{L}$ & $\mathrm{M}$ & $\mathrm{L}$ & $\mathrm{M}$ & L & $\mathrm{M}$ & L & M & L & $\mathrm{M}$ & L & $\mathrm{M}$ & L & $\mathrm{M}$ & L & $\mathrm{M}$ \\
\hline Joelho & & & & & & & & & & & & & & & & \\
\hline Cotovelo & & & & & & & & & & & & & & & & \\
\hline Tornozelo & & & & & & & & & & & & & & & & \\
\hline Quadril & & & & & & & & & & & & & & & & \\
\hline Ombro & & & & & & & & & & & & & & & & \\
\hline Outras: & & & & & & & & & & & & & & & & \\
\hline
\end{tabular}

Última hemartrose e provável etiologia:

Consulta

Após trauma (T) Espontâneo (E) Indefinido (I)

\begin{tabular}{|l|l|l|l|}
\hline $1 \mathrm{a}$ & $2 \mathrm{a}$ & $3 \mathrm{a}$ & $4 \mathrm{a}$ \\
\hline
\end{tabular}

Hemorragias Musculares:

Consulta

Presente (+)

Ausente (-)

\begin{tabular}{|l|l|l|l|}
\hline $1 \mathrm{a}$ & $2 \mathrm{a}$ & $3 \mathrm{a}$ & $4 \mathbf{a}$ \\
\hline & & & \\
\hline
\end{tabular}

Localização das Hemorragias Musculares:

\begin{tabular}{|c|c|c|c|c|c|c|c|c|}
\hline Consulta & \multicolumn{2}{|c|}{$1 \mathrm{a}$} & \multicolumn{2}{|c|}{$2 a$} & \multicolumn{2}{|c|}{$3 a$} & \multicolumn{2}{|c|}{$4 a$} \\
\hline Direito (D) Esquerdo (E) & $\mathrm{D}$ & E & $\mathrm{D}$ & $\mathrm{E}$ & $\mathrm{D}$ & $\mathrm{E}$ & $\mathrm{D}$ & $\mathrm{E}$ \\
\hline Antebraço & & & & & & & & \\
\hline Panturrilha & & & & & & & & \\
\hline Ileopsoas & & & & & & & & \\
\hline Glúteo & & & & & & & & \\
\hline Coxa & & & & & & & & \\
\hline Deltóide & & & & & & & & \\
\hline Bíceps & & & & & & & & \\
\hline Outros & & & & & & & & \\
\hline
\end{tabular}

Comprometimento Nervoso Periférico:

\begin{tabular}{|c|c|c|c|c|c|}
\hline Consulta & & $1 \mathrm{a}$ & $2 a$ & $3 a$ & $4 a$ \\
\hline Presente (+) & Ausente (-) & & & & \\
\hline
\end{tabular}


Localização do comprometimento Nervoso Periférico:

\begin{tabular}{|l|c|c|c|c|c|c|c|c|}
\hline Consulta & \multicolumn{2}{|c|}{ 1a } & \multicolumn{2}{|c|}{ 2a } & \multicolumn{2}{|c|}{ 3a } & \multicolumn{2}{c|}{$4 \mathrm{a}$} \\
\hline Direito (D) Esquerdo (E) & D & E & D & E & D & E & D & E \\
\hline Nervo mediano & & & & & & & & \\
\hline Nervo ulnar & & & & & & & & \\
\hline Nervo femoral & & & & & & & & \\
\hline Nervo tibial posterior & & & & & & & & \\
\hline Outros & & & & & & & & \\
\hline
\end{tabular}

Freqüência das hemorragias musculares, tipos e características (anotar, no quadro, o número de episódios)

Consulta

Direito (D

Esquerdo (E)

Leve (L)

Moderado (M)

Antebraço

Panturrilha

Ileopsoas

Glúteo

Coxa

Deltóide

Bíceps

Outros

\begin{tabular}{|c|c|c|c|c|c|c|c|c|c|c|c|c|c|c|c|}
\hline \multicolumn{3}{|c|}{ 1a } & \multicolumn{3}{|c|}{ 2a } & \multicolumn{2}{|c|}{ E } & \multicolumn{2}{|c|}{ D } & \multicolumn{2}{c|}{ E } & \multicolumn{3}{c|}{ D } & \multicolumn{2}{c|}{ E } & \multicolumn{3}{|c|}{ D } & \multicolumn{2}{|c|}{ E } \\
\hline L & M & L & M & L & M & L & M & L & M & L & M & L & M & L & M \\
\hline & & & & & & & & & & & & & & & \\
\hline & & & & & & & & & & & & & & & \\
\hline & & & & & & & & & & & & & & & \\
\hline & & & & & & & & & & & & & & & \\
\hline & & & & & & & & & & & & & & & \\
\hline
\end{tabular}

Última hemorragia muscular e provável etiologia

Consulta

Após trauma (T)

Espontânea (E)

Indefinida (I)

\begin{tabular}{|l|l|l|l|}
\hline $1 \mathrm{a}$ & $2 \mathrm{a}$ & $3 \mathrm{a}$ & $4 \mathrm{a}$ \\
\hline
\end{tabular}

Hemorragias do Subcutâneo

Consulta

Presente (+)

Ausente (-)

\begin{tabular}{|l|l|l|l|}
\hline $1 \mathrm{a}$ & $2 \mathrm{a}$ & $3 \mathrm{a}$ & $4 \mathrm{a}$ \\
\hline & & & \\
\hline
\end{tabular}

Localização das hemorragias do Subcutâneo

Consulta

Direito (D) Esquerdo (E)

Região Frontal

Região Occipital

Crista da Tíbia

Complicações:

\begin{tabular}{|l|c|c|c|c|c|}
\hline Consulta & $1 \mathrm{a}$ & $2 \mathrm{a}$ & $3 \mathrm{a}$ & $4 \mathrm{a}$ \\
\hline Ausente (-) Infecção (I) Drenagem Espontânea (DE) & & & & \\
\hline
\end{tabular}

\section{EXAME FÍSICO:}

Estado Geral:

\begin{tabular}{|l|c|c|c|c|c|}
\hline Consulta & $1 \mathrm{a}$ & $2 \mathrm{a}$ & $3 \mathrm{a}$ & $4 \mathrm{a}$ \\
\hline Bom (B) Regular (R) Mau (M) & & & & \\
\hline
\end{tabular}


Deambulação

Consulta

Independente (I) Muletas Auxiliares (MA) Órteses (O)

Uso de órteses + muletas (OM) Cadeira de Rodas (CR)

Amplitude de Movimento:

\begin{tabular}{|c|c|c|c|c|c|c|c|c|}
\hline Consulta & \multicolumn{2}{|c|}{$1 \mathrm{a}$} & \multicolumn{2}{|c|}{$2 a$} & \multicolumn{2}{|c|}{$3 \mathbf{a}$} & \multicolumn{2}{|c|}{$4 a$} \\
\hline Direito (D) Esquerdo (E) & $\mathrm{D}$ & E & $\mathrm{D}$ & $\mathrm{E}$ & $\mathrm{D}$ & $\mathrm{E}$ & $\mathrm{D}$ & $\mathrm{E}$ \\
\hline Extensão do Joelho (normal $=0^{\circ}$ ) & & & & & & & & \\
\hline Flexão do Joelho $\left(\right.$ normal $=130^{\circ}$ ) & & & & & & & & \\
\hline Dorsiflexão do tornozelo (normal = & & & & & & & & \\
\hline Flexão Plantar do tornozelo (norma & & & & & & & & \\
\hline Extensão do quadril ( normal $=0^{\circ}$ ) & & & & & & & & \\
\hline Flexão do quadril $\left(\right.$ normal $\left.=120^{\circ}\right)$ & & & & & & & & \\
\hline Extensão do cotovelo (normal $=0^{\circ}$ ) & & & & & & & & \\
\hline Flexão do cotovelo $\left(\right.$ normal $\left.=120^{\circ}\right)$ & & & & & & & & \\
\hline
\end{tabular}

Escore Clínico para o Joelho

\begin{tabular}{|c|c|c|c|c|c|c|c|c|}
\hline Consulta & & & & & & & & \\
\hline Direito (D) Esquerdo (E) & $\mathrm{D}$ & E & $\mathrm{D}$ & $\mathrm{E}$ & $\mathrm{D}$ & $\mathrm{E}$ & D & $\mathrm{E}$ \\
\hline Não $=\mathbf{0} \quad$ Sim $=\mathbf{2} \quad$ Sinovite crônica $=\mathbf{S}$ & & & & & & & & \\
\hline Não $=\mathbf{0} \quad$ Leve $=\mathbf{1} \quad$ Intensa $=\mathbf{2}$ & & & & & & & & \\
\hline Não ou mínima $=0$ & & & & & & & & \\
\hline $\begin{array}{rr}\text { 4. Deformidade axial: } & 0-7^{\circ} \text { valgo }=0 \\
8-15^{\circ} \text { yalo ou } 0-5^{\circ} \text { yaro }=1 \quad>15^{\circ} \text { yalgo ou }>5^{\circ} \text { varo }=2\end{array}$ & & & & & & & & \\
\hline Não $=0 \quad \mathrm{Sim}=1$ & & & & & & & & \\
\hline $\begin{array}{l}\text { 6. Amplitude de movimento } \\
\text { normal ou }<10 \%=0\end{array}$ & & & & & & & & \\
\hline 7. Contratura em flexão & & & & & & & & \\
\hline 8. Instabilidade: & & & & & & & & \\
\hline TOTAL (0 a 14) & & & & & & & & \\
\hline
\end{tabular}

Escore Clínico para o Cotovelo

\begin{tabular}{|c|c|c|c|c|c|c|c|c|}
\hline Consulta & & & & & & & & \\
\hline Direito (D) Esquerdo (E) & $\mathrm{D}$ & $\mathrm{E}$ & $\mathrm{D}$ & $\mathrm{E}$ & $\mathrm{D}$ & $\mathrm{E}$ & $\mathrm{D}$ & E \\
\hline Não $=0 \quad$ Sim $=2 \quad$ Sinovite crônica $=\mathbf{S}$ & & & & & & & & \\
\hline Não $=\mathbf{0} \quad$ Leve $=\mathbf{1} \quad$ Intensa $=\mathbf{2}$ & & & & & & & & \\
\hline Não ou mínima = 0 & & & & & & & & \\
\hline Não $=\mathbf{0} \quad$ Sim $=\mathbf{1}$ & & & & & & & & \\
\hline $\begin{array}{l}\text { 5. Amplitude de movimento } \\
\text { normal ou }<10 \%=0\end{array}$ & & & & & & & & \\
\hline 6. Instabilidade: & & & & & & & & \\
\hline TOTAL (0 a 10) & & & & & & & & \\
\hline
\end{tabular}


Escore Clínico para o Tornozelo

Consulta

Direito (D) Esquerdo (E)

1. Edema: $\quad$ Não $=\mathbf{0} \quad$ Sim $=\mathbf{2}$ Sinovite crônica $=\mathbf{S}$

$\begin{array}{llll}\text { 2. Dor: } & \text { Não }=\mathbf{0} & \text { Leve }=\mathbf{1} & \text { Intensa }=\mathbf{2}\end{array}$

3. Atrofia:

Não ou mínima $=\mathbf{0} \quad \operatorname{Sim}=\mathbf{1}$

4. Deformidade axial: sem deformidade $=\mathbf{0}$

$<10^{\circ}$ de valgo ou $<5^{\circ}$ varo $=1>10^{\circ}$ valgo ou $>5^{\circ}$ varo $=2$

5. Crepitação

6. Amplitude de movimento normal ou $<10 \%=0$

7. Contratura em flexão

8. Instabilidade: $\quad$ Não $=\mathbf{0} \quad$ Leve $=\mathbf{1} \quad$ Grave $=\mathbf{2}$

TOTAL (0 a 14)

Não $=\mathbf{0} \quad$ Sim $=\mathbf{1}$

\begin{tabular}{|c|c|c|c|c|c|c|c|c|}
\hline \multicolumn{2}{|c|}{ 1a } & \multicolumn{2}{c|}{$2 \mathrm{a}$} & \multicolumn{2}{c|}{$3 \mathrm{a}$} & \multicolumn{2}{c|}{$4 \mathrm{a}$} \\
\hline $\mathrm{D}$ & $\mathrm{E}$ & $\mathrm{D}$ & $\mathrm{E}$ & $\mathrm{D}$ & $\mathrm{E}$ & $\mathrm{D}$ & $\mathrm{E}$ \\
\hline & & & & & & & \\
\hline & & & & & & & \\
\hline & & & & & & & \\
\hline & & & & & & & \\
\hline & & & & & & & \\
\hline & & & & & & & \\
\hline & & & & & & & \\
\hline
\end{tabular}

Escore Clínico para o Quadril

Consulta

Direito (D) Esquerdo (E)

1. Edema: $\quad$ Não $=\mathbf{0} \quad$ Sim $=\mathbf{2}$ Sinovite crônica $=\mathbf{S}$

\begin{tabular}{llll}
\hline 2. Dor: & Não $=\mathbf{0}$ & Leve $=\mathbf{1}$ & Intensa $=\mathbf{2}$
\end{tabular}

3. Atrofia:

Não ou mínima $=\mathbf{0} \quad \operatorname{Sim}=\mathbf{1}$

4. Crepitação

5. Amplitude de movimento

Não $=\mathbf{0} \quad \operatorname{Sim}=\mathbf{1}$

normal ou $<10 \%=0$

6. Contratura em flexão

7. Instabilidade:

TOTAL (0 a 12)

10 a $30 \%=1>30 \%=2$

Não $=\mathbf{0} \quad<15 \%=\mathbf{1}>15 \%=\mathbf{2}$

Não $=\mathbf{0} \quad$ Leve $\mathbf{= 1} \quad$ Grave $=\mathbf{2}$

\begin{tabular}{|c|c|c|c|c|c|c|c|c|}
\hline \multicolumn{2}{|c|}{ 1a } & \multicolumn{2}{c|}{ 2a } & \multicolumn{3}{c|}{$3 \mathrm{a}$} & \multicolumn{2}{c|}{ 4a } \\
\hline $\mathrm{D}$ & $\mathrm{E}$ & $\mathrm{D}$ & $\mathrm{E}$ & $\mathrm{D}$ & $\mathrm{E}$ & $\mathrm{D}$ & $\mathrm{E}$ \\
\hline & & & & & & & \\
\hline & & & & & & & \\
\hline & & & & & & & \\
\hline & & & & & & & \\
\hline & & & & & & & \\
\hline & & & & & & & \\
\hline & & & & & & & \\
\hline
\end{tabular}

Escore Clínico para o Ombro

Consulta

Direito (D) Esquerdo (E)

1. Edema:

Não $=\mathbf{0} \quad$ Sim $=\mathbf{2}$ Sinovite crônica $=\mathbf{S}$

2. Dor:

Não $=\mathbf{0} \quad$ Leve $=\mathbf{1} \quad$ Intensa $=\mathbf{2}$

3. Atrofia:

Não ou mínima $=\mathbf{0} \quad$ Sim $=\mathbf{1}$

4. Crepitação

Não $=\mathbf{0} \quad$ Sim $=1$

5. Amplitude de movimento normal ou $<10 \%=0$

6. Instabilidade: $\quad$ Não $=\mathbf{0}$

10 a $30 \%=1 \quad>30 \%=2$

TOTAL (0 a 10)

\begin{tabular}{|c|c|c|c|c|c|c|c|}
\hline \multicolumn{2}{|c|}{$1 \mathrm{a}$} & \multicolumn{2}{c|}{$2 \mathrm{2a}$} & \multicolumn{2}{c|}{$3 \mathrm{a}$} & \multicolumn{2}{c|}{$4 \mathrm{a}$} \\
\hline $\mathrm{D}$ & $\mathrm{E}$ & $\mathrm{D}$ & $\mathrm{E}$ & $\mathrm{D}$ & $\mathrm{E}$ & $\mathrm{D}$ & $\mathrm{E}$ \\
\hline & & & & & & & \\
\hline & & & & & & & \\
\hline & & & & & & & \\
\hline & & & & & & & \\
\hline & & & & & & & \\
\hline & & & & & & & \\
\hline
\end{tabular}

Escore Radiológico para o Joelho:

Consulta

Direito (D) Esquerdo (E)

1. Osteoporose

2. Alargamentos das Epífises

3. Irregularidades da superfície subcondral

Não $=\mathbf{0} \quad$ Leve $=\mathbf{1} \quad$ Acentuada $=\mathbf{2}$

\begin{tabular}{|c|c|c|c|c|c|c|c|c|c|}
\hline & & \multicolumn{2}{|c|}{$1 \mathrm{a}$} & \multicolumn{2}{|c|}{$2 a$} & \multicolumn{2}{|c|}{$3 a$} & \multicolumn{2}{|c|}{$4 a$} \\
\hline & & $\mathrm{D}$ & $\mathrm{E}$ & $\mathrm{D}$ & $\mathrm{E}$ & D & $\mathrm{E}$ & $\mathrm{D}$ & $\mathrm{E}$ \\
\hline Não $=0$ & $\mathrm{Sim}=1$ & & & & & & & & \\
\hline Não $=0$ & $\operatorname{Sim}=1$ & & & & & & & & \\
\hline Acer & $\operatorname{tada}=\mathbf{2}$ & & & & & & & & \\
\hline
\end{tabular}




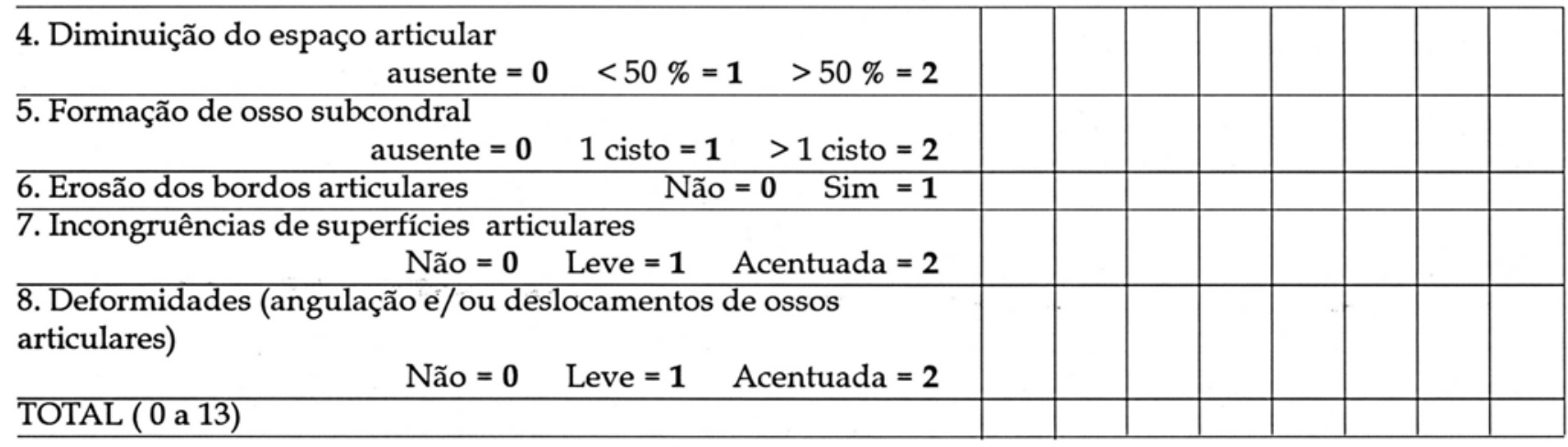

Escore Radiológico para o Cotovelo:

\begin{tabular}{|c|c|c|c|c|c|c|c|c|}
\hline Consulta & & & & & & & & \\
\hline Direito (D) Esquerdo (E) & $\mathrm{D}$ & $\mathrm{E}$ & $\mathrm{D}$ & $\mathrm{E}$ & $\mathrm{D}$ & $\mathrm{E}$ & $\mathrm{D}$ & E \\
\hline Não $=\mathbf{0} \quad$ Sim = 1 & & & & & & & & \\
\hline 2. Alargamentos das Epífises & & & & & & & & \\
\hline 3. Irregularidades da superfície subcondral & & & & & & & & \\
\hline $\begin{array}{l}\text { 4. Diminuição do espaço articular } \\
\qquad \begin{array}{l}\text { ausente }=0 \quad<50 \%=1 \quad>50 \%=2\end{array}\end{array}$ & & & & & & & & \\
\hline $\begin{array}{l}\text { 5. Formação de osso subcondral } \\
\qquad \begin{array}{l}\text { ausente }=0 \quad 1 \text { cisto }=1 \quad>1 \text { cisto }=\mathbf{2}\end{array}\end{array}$ & & & & & & & & \\
\hline 6. Erosão dos bordos articulares & & & & & & & & \\
\hline $\begin{array}{l}\text { 7. Incongruências de superfícies articulares } \\
\qquad \text { Não }=0 \quad \text { Leve }=\mathbf{1} \quad \text { Acentuada }=\mathbf{2}\end{array}$ & & & & & & & & \\
\hline $\begin{array}{l}\text { 8. Deformidades (angulação e/ou deslocamentos de ossos } \\
\text { articulares) } \\
\qquad \text { Não }=\mathbf{0} \quad \text { Leve }=\mathbf{1} \quad \text { Acentuada }=\mathbf{2}\end{array}$ & & & & & & & & \\
\hline TOTAL ( 0 a 13) & & & & & & & & \\
\hline
\end{tabular}

Escore Radiológico para o Tornozelo:

\begin{tabular}{|c|c|c|c|c|c|c|c|c|}
\hline Consulta & & & & & & & & \\
\hline$\overline{\text { Direito (D)· Esquerdo (E) }}$ & $\mathrm{D}$ & E & $\mathrm{D}$ & $\mathrm{E}$ & $\mathrm{D}$ & $\mathrm{E}$ & $\mathrm{D}$ & $\mathrm{E}$ \\
\hline Não $=\mathbf{0} \quad$ Sim $=\mathbf{1}$ & & & & & & & & \\
\hline 2. Alargamentos das Epífises & & & & & & & & \\
\hline $\begin{array}{l}\text { 3. Irregularidades da superfície subcondral } \\
\qquad \text { Não }=0 \quad \text { Leve }=\mathbf{1} \quad \text { Acentuada }=\mathbf{2}\end{array}$ & & & & & & & & \\
\hline $\begin{array}{l}\text { 4. Diminuição do espaço articular } \\
\qquad \begin{array}{l}\text { ausente }=0 \quad<50 \%=1 \quad>50 \%=2 \\
\end{array}\end{array}$ & & & & & & & & \\
\hline $\begin{array}{l}\text { 5. Formação de osso subcondral } \\
\qquad \begin{array}{l}\text { ausente }=0 \\
\quad 1 \text { cisto }=1 \quad>1 \text { cisto }=\mathbf{2}\end{array}\end{array}$ & & & & & & & & \\
\hline 6. Erosão dos bordos articulares & & & & & & & & \\
\hline $\begin{array}{l}\text { 7. Incongruências de superfícies articulares } \\
\qquad \text { Não }=0 \quad \text { Leve }=\mathbf{1} \quad \text { Acentuada }=\mathbf{2}\end{array}$ & & & & & & & & \\
\hline $\begin{array}{l}\text { 8. Deformidades (angulação e/ou deslocamentos de ossos } \\
\text { articulares) } \\
\qquad \text { Não }=\mathbf{0} \quad \text { Leve }=\mathbf{1} \quad \text { Acentuada }=\mathbf{2}\end{array}$ & & & & & & & & \\
\hline TOTAL ( 0 a 13) & & & & & & & & \\
\hline
\end{tabular}


Escore Radiológico para o Quadril:

\begin{tabular}{|c|c|c|c|c|c|c|c|c|}
\hline Consulta & & & & & & & & \\
\hline Direito (D) Esquerdo (E) & $\mathrm{D}$ & E & $\mathrm{D}$ & $\mathrm{E}$ & $\mathrm{D}$ & $\mathrm{E}$ & $\mathrm{D}$ & $\mathbf{E}$ \\
\hline 1. Osteoporose & & & & & & & & \\
\hline 2. Alargamentos das Epífises & & & & & & & & \\
\hline $\begin{array}{l}\text { 3. Irregularidades da superfície subcondral } \\
\qquad \text { Não }=\mathbf{0} \quad \text { Leve }=\mathbf{1}\end{array}$ & & & & & & & & \\
\hline $\begin{array}{l}\text { 4. Diminuição do espaço articular } \\
\qquad \begin{array}{l}\text { ausente }=0 \\
\qquad 50 \%=1 \quad>50 \%=2\end{array}\end{array}$ & & & & & & & & \\
\hline $\begin{array}{l}\text { 5. Formação de osso subcondral } \\
\qquad \begin{array}{l}\text { ausente }=0 \quad 1 \text { cisto }=1 \quad>1 \text { cisto }=2\end{array}\end{array}$ & & & & & & & & \\
\hline 6. Erosão dos bordos articulares & & & & & & & & \\
\hline $\begin{array}{l}\text { 7. Incongruências de superfícies articulares } \\
\qquad \text { Não }=0 \quad \text { Leve }=\mathbf{1}\end{array}$ & & & & & & & & \\
\hline $\begin{array}{l}\text { 8. Deformidades (angulação e/ou deslocamentos de ossos } \\
\text { articulares) } \\
\qquad \text { Não }=\mathbf{0} \quad \text { Leve }=\mathbf{1} \quad \text { Acentuada = } 2\end{array}$ & & & & & & & & \\
\hline TOTAL ( 0 a 13) & & & & & & & & \\
\hline
\end{tabular}

Escore Radiológico para o Ombro:

\begin{tabular}{|c|c|c|c|c|c|c|c|c|}
\hline Consulta & & & & & & & & \\
\hline Direito (D) Esquerdo (E) & $\mathrm{D}$ & E & $\mathrm{D}$ & E & $\mathrm{D}$ & E & $\mathrm{D}$ & E \\
\hline Não $=\mathbf{0} \quad$ Sim $=\mathbf{1}$ & & & & & & & & \\
\hline 2. Alargamentos das Epífises & & & & & & & & \\
\hline 3. Irregularidades da superfície subcondral & & & & & & & & \\
\hline Acentuada $=\mathbf{2}$ & & & & & & & & \\
\hline $\begin{array}{l}\text { 4. Diminuição do espaço articular } \\
\qquad \begin{array}{l}\text { ausente }=0 \\
\qquad 50 \%=1 \quad>50 \%=2\end{array}\end{array}$ & & & & & & & & \\
\hline $\begin{array}{l}\text { 5. Formação de osso subcondral } \\
\qquad \begin{array}{l}\text { ausente }=0 \quad 1 \text { cisto }=1 \quad>1 \text { cisto }=\mathbf{2}\end{array}\end{array}$ & & & & & & & & \\
\hline $\begin{array}{lll}\text { 6. Erosão dos bordos articulares } & \text { Não }=\mathbf{0} & \text { Sim }=\mathbf{1}\end{array}$ & & & & & & & & \\
\hline $\begin{array}{l}\text { 7. Incongruências de superfícies articulares } \\
\qquad \text { Não }=0 \quad \text { Leve }=1\end{array}$ & & & & & & & & \\
\hline $\begin{array}{l}\text { 8. Deformidades (angulação e/ou deslocamentos de ossos } \\
\text { articulares) } \\
\qquad \text { Não }=\mathbf{0} \quad \text { Leve }=\mathbf{1} \quad \text { Acentuada }=\mathbf{2}\end{array}$ & & & & & & & & \\
\hline DTAL ( 0 a 13) & & & & & & & & \\
\hline
\end{tabular}


Resumo das Avaliações

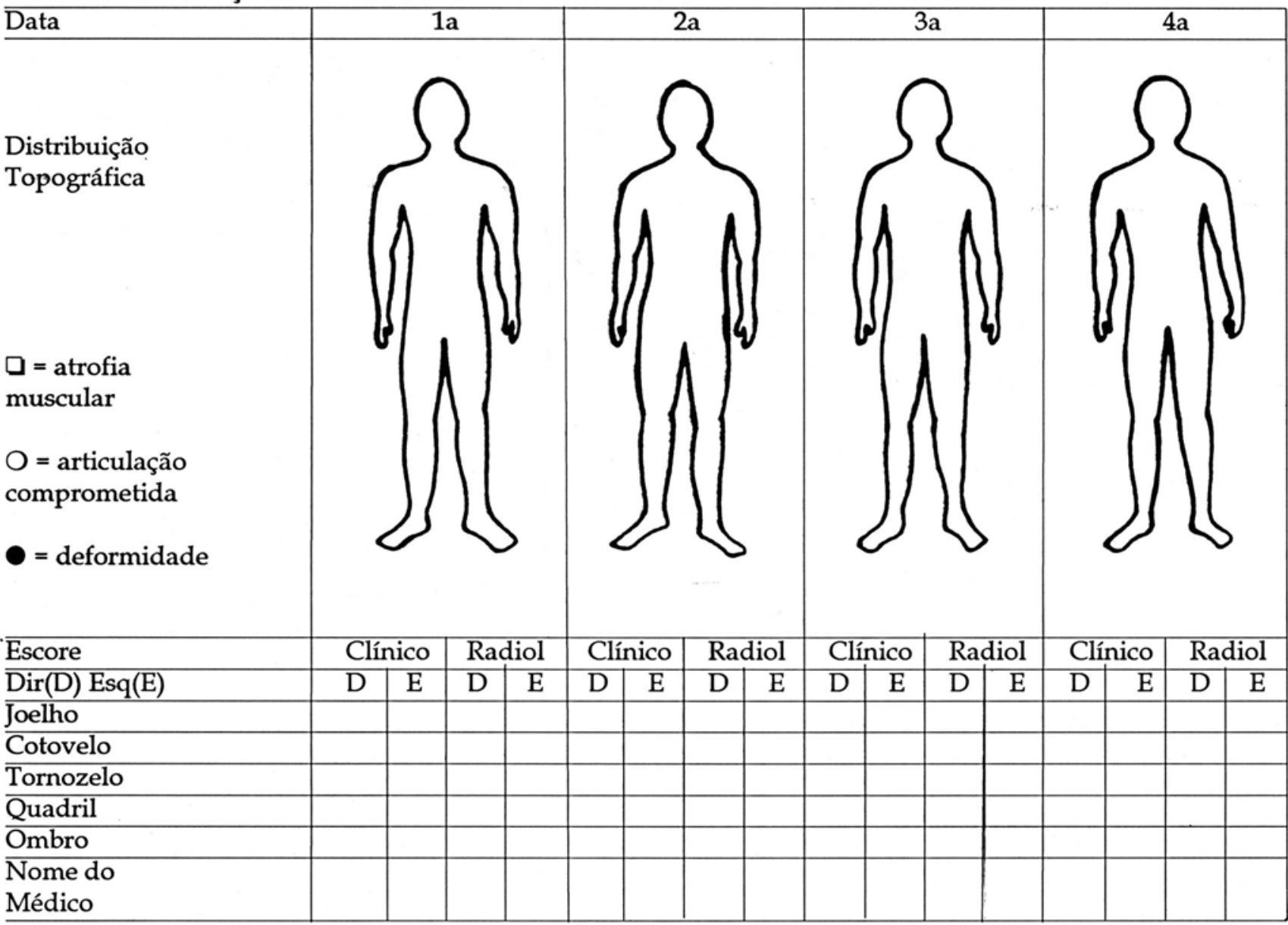

Dados Complementares do Aparelho Locomotor:

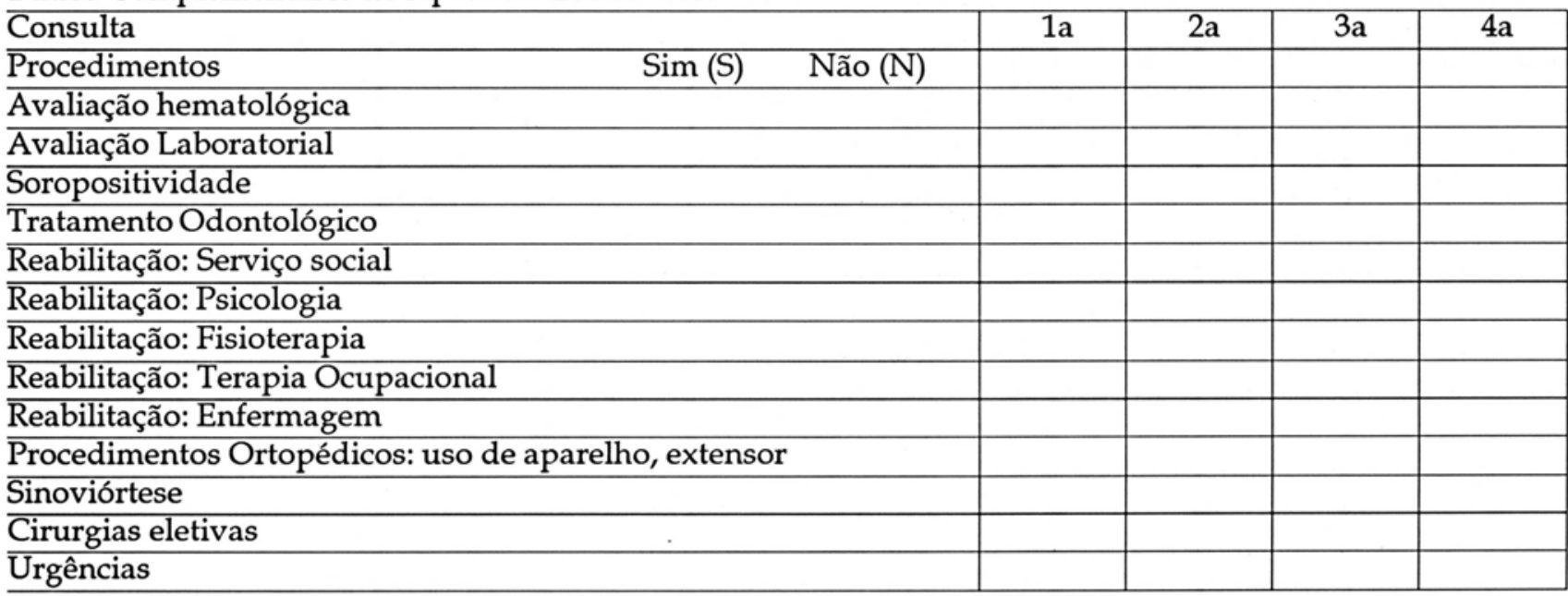

